\title{
Eddy covariance flux measurements of pollutant gases in urban Mexico City
}

\author{
E. Velasco ${ }^{1,3, *}$, S. Pressley ${ }^{2}$, R. Grivicke ${ }^{2}$, E. Allwine ${ }^{2}$, T. Coons ${ }^{2}$, W. Foster ${ }^{2}$, B. T. Jobson ${ }^{2}$, H. Westberg ${ }^{2}$, \\ R. $\operatorname{Ramos}^{4,{ }^{* *}}$, F. Hernández ${ }^{4}$, L. T. Molina ${ }^{1,3}$, and B. Lamb ${ }^{2}$ \\ ${ }^{1}$ Molina Center for Energy and the Environment (MCE2), La Jolla, CA, USA \\ ${ }^{2}$ Laboratory for Atmospheric Research, Dept. of Civil and Environmental Engineering, Washington State University, \\ Pullman, WA, USA \\ ${ }^{3}$ Department of Earth, Atmospheric and Planetary Sciences, Massachusetts Institute of Technology, Cambridge, MA, USA \\ ${ }^{4}$ Secretaría del Medio Ambiente del Gobierno del Distrito Federal, México D.F., México \\ * now at: Dept. of Geography, Faculty of Arts and Social Sciences, National University of Singapore, Singapore \\ ** now at: William J. Clinton Foundation, Clinton Climate Initiative, México D.F., México
}

Received: 5 March 2009 - Published in Atmos. Chem. Phys. Discuss.: 25 March 2009

Revised: 7 September 2009 - Accepted: 14 September 2009 - Published: 2 October 2009

\begin{abstract}
Eddy covariance (EC) flux measurements of the atmosphere/surface exchange of gases over an urban area are a direct way to improve and evaluate emissions inventories, and, in turn, to better understand urban atmospheric chemistry and the role that cities play in regional and global chemical cycles. As part of the MCMA-2003 study, we demonstrated the feasibility of using eddy covariance techniques to measure fluxes of selected volatile organic compounds (VOCs) and $\mathrm{CO}_{2}$ from a residential district of Mexico City (Velasco et al., 2005a, b). During the MILAGRO/MCMA2006 field campaign, a second flux measurement study was conducted in a different district of Mexico City to corroborate the 2003 flux measurements, to expand the number of species measured, and to obtain additional data for evaluation of the local emissions inventory. Fluxes of $\mathrm{CO}_{2}$ and olefins were measured by the conventional $\mathrm{EC}$ technique using an open path $\mathrm{CO}_{2}$ sensor and a Fast Isoprene Sensor calibrated with a propylene standard. In addition, fluxes of toluene, benzene, methanol and $\mathrm{C}_{2}$-benzenes were measured using a virtual disjunct EC method with a Proton Transfer Reaction Mass Spectrometer. The flux measurements were analyzed in terms of diurnal patterns and vehicular activity and were compared with the most recent gridded local emissions inventory. In both studies, the results showed that the urban surface of Mexico City is a net source of $\mathrm{CO}_{2}$ and VOCs with significant contributions from vehicular traffic. Evap-
\end{abstract}

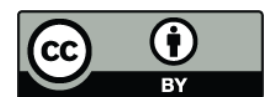

Correspondence to: E. Velasco (evelasco@mce2.org) orative emissions from commercial and other anthropogenic activities were significant sources of toluene and methanol. The results show that the emissions inventory is in reasonable agreement with measured olefin and $\mathrm{CO}_{2}$ fluxes, while $\mathrm{C}_{2}$-benzenes and toluene emissions from evaporative sources are overestimated in the inventory. It appears that methanol emissions from mobile sources occur, but are not reported in the mobile emissions inventory.

\section{Introduction}

Accurate estimates of emission rates and patterns for precursor and pollutant gases and aerosols from a wide range of sources within an urban area are necessary to support effective air quality management strategies. Similarly, accurate emission inventories are needed as a foundation for understanding the role of large cities within atmospheric chemistry occurring at regional and global scales. Given the rapid growth of the number and size of mega-cities coupled with the complexity of urban landscapes, assessment of the uncertainty in emission inventories requires a combination of both direct and indirect methods. This is particularly true for urban areas in the developing world, where in many cases only limited emission data are available.

Emission inventories are typically constructed through a bottom-up aggregation process that accounts for emission rates, activity levels, and source distributions. Emission rates are often derived from laboratory or specific field measurements (e.g., vehicle dynamometer studies), activity levels can

Published by Copernicus Publications on behalf of the European Geosciences Union. 
be obtained from traffic counts, surveys of sources and other information, and source distributions may come from roadway maps, aerial photographs, or estimated from population density. The large uncertainties associated with this bottomup process reduce the utility of emission inventories, and consequently impede the air quality management process.

One way to evaluate emissions inventories is to make direct measurements of pollutant fluxes that include all major industrial and mobile sources and minor commercial and residential sources from a determined region and compare these measurements directly with the estimated emissions. In a city, the footprint for these measurements should be similar in size to the cells in gridded emission inventories used for air quality modeling (1 to $3 \mathrm{~km}$ on a side). Measurements on this scale can be accomplished using fast response analytical sensors with eddy covariance (EC) techniques. EC techniques have been successfully applied in the past to evaluate biogenic fluxes of carbon dioxide $\left(\mathrm{CO}_{2}\right)$ and selected species of volatile organic compounds (VOCs) from forests and croplands (Schmid et al., 2000; Westberg et al., 2001; Karl et al., 2001). During the last decade, the same techniques have been used in urban environments to measure fluxes of $\mathrm{CO}_{2}$ (Grimmond et al., 2002; Nemitz et al., 2002) and more recently fluxes of VOCs (Velasco et al., 2005a; Langford et al., 2009; Karl et al., 2009).

We deployed an urban VOC flux system (Velasco et al., 2005a, b) at the CENICA supersite located in the southeast of the city during the Mexico City Metropolitan Area (MCMA2003) field campaign (Molina et al., 2007). The objective was to evaluate the VOCs emissions inventory of Mexico City, and, in particular, to investigate whether the VOC emissions inventory was underestimated by a factor of 3 , as suggested from the analysis of past measurements of $\mathrm{VOC} / \mathrm{NO}_{\mathrm{x}}$ ratios (Arriaga-Colina et al., 2004) and from ozone modeling (West et al., 2004). This flux system demonstrated the feasibility of the EC techniques to measure fluxes of VOCs from an urban landscape. Results showed that for olefins and the aromatic VOCs measured in the residential sector of Mexico City, the emissions inventory was generally accurate. The conclusion was corroborated by the ozone modeling studies using MCMA-2003 measurements (Lei et al., 2007, 2008). An obvious question is whether these results would hold for other locations in the city and for other VOC compounds.

As part of the MCMA-2006 study, a component of the Megacity Initiative: Local and Global Research Observations (MILAGRO) project conducted during March 2006 (Molina et al., 2008), we deployed an enhanced flux system in a different district of Mexico City to corroborate the 2003 flux measurements, to expand the number of species measured, and to obtain additional data for evaluation of the local emissions inventory. We employed a chemiluminescent isoprene analyzer calibrated to measure fluxes of olefins (Fast Olefin Sensor, FOS) and an open-path infrared gas analyzer (IRGA) to measure fluxes of $\mathrm{CO}_{2}$ and water vapor; both instruments were used with the conventional $\mathrm{EC}$ technique.
A Proton Transfer Reaction - Mass Spectrometer (PTR-MS) was used to measure fluxes of benzene, toluene, $\mathrm{C}_{2}$-benzenes and methanol through a virtual Disjunct Eddy Covariance (DEC) method similar to the method developed by Karl et al. (2002). Flux estimates for individual non-methane hydrocarbons were also obtained using a Disjunct Eddy Accumulation (DEA) method, where canister samples were collected and subsequently analyzed using Flame Ionization Detection Gas Chromatography (FID-GC). Results for the DEA measurements are reported in a separate manuscript (Velasco et al., 2009a). For the EC and DEC methods, the measured fluxes were analyzed in terms of diurnal patterns and vehicular activity for the location, and were used to evaluate the most recent local $\mathrm{CO}_{2}$ and $\mathrm{VOC}$ emissions inventory.

The MCMA-2006 study also included aerosol and energy flux measurements. An Aerodyne Quadrupole Aerosol Mass Spectrometer (AMS) operated in EC mode was used to measure fluxes of speciated aerosols (organics, nitrate, sulfate, ammonium and chloride). Fluxes of latent and sensible heat, net radiation and momentum were also measured. Results from the AMS operation and the energy balance will be presented in separate papers (Grivicke et al., 2009; Velasco et al., 2009b).

The main objective of the MILAGRO campaign was to evaluate the regional and hemispheric impacts of the Mexico City urban plume on atmospheric chemical cycling (Molina et al., 2008). Our measurements were designed to provide information on the composition of the urban plume before it leaves the city. Our specific objectives included: 1) flux measurement of VOC rates and patterns for a range of compounds on a continuous basis at a site near the center of Mexico City using a combination of EC, DEC, and DEA methods; 2) complementary flux measurements of aerosols, $\mathrm{CO}_{2}$, $\mathrm{H}_{2} \mathrm{O}$, sensible and latent heat, net radiation and momentum; and 3) evaluation of the most current Mexico City emissions inventory.

\section{Methods}

\subsection{Measurement site and study period}

The flux measurements were conducted from a $25 \mathrm{~m}$ walkup tower mounted on the rooftop of the headquarters of the local air quality management agency (SIMAT). The measurement height was $42 \mathrm{~m}$ above street level, which is more than 3 times the mean height of the surrounding buildings $\left(\mathrm{z}_{h}=12\right.$ $\mathrm{m})$, and of sufficient height to be in the constant flux layer. The flux system was located in a busy district (Escandon district: $19^{\circ} 24^{\prime} 12.63^{\prime \prime} \mathrm{N}, 99^{\circ} 10^{\prime} 34.18^{\prime \prime} \mathrm{W}$, and $2240 \mathrm{~m}$ above sea level) surrounded by congested avenues and close to the center of the city. According to the local emissions inventory this site is one of the residential areas in the city with the highest VOC emissions (SMAGDF, 2008). The surrounding topography is flat and relatively homogeneous in terms 
Table 1. Summary of ambient concentration and flux measurements from MILAGRO/MCMA-2006 field campaign during March 2006.

\begin{tabular}{|c|c|c|c|c|c|c|}
\hline Compound & Measured days ${ }^{\mathrm{a}}$ & $\begin{array}{l}\text { Number of } 30 \mathrm{~min} . \\
\text { periods }^{\mathrm{b}}\end{array}$ & $\begin{array}{l}24 \mathrm{~h} \text { median concentration } \\
(\mathrm{ppbv})^{\mathrm{c}}\end{array}$ & $\begin{array}{l}\text { Morning rush-hour } \\
\text { period (6-9 a.m.) } \\
\text { mean concentration (ppbv) }{ }^{\mathrm{c}}\end{array}$ & $\begin{array}{l}24 \mathrm{~h} \text { mean flux } \\
\left(\mu \mathrm{g} \mathrm{m}^{-2} \mathrm{~s}^{-1}\right)^{\mathrm{c}}\end{array}$ & $\begin{array}{l}7 \text { a.m. }-3 \text { p.m. } \\
\text { mean flux } \\
\left(\mu \mathrm{g} \mathrm{m}^{-2} \mathrm{~s}^{-1}\right)^{\mathrm{c}}\end{array}$ \\
\hline $\mathrm{CO}_{2}$ & $65-89$ (24) & 933 (1092) & $409 \pm 9^{d}$ & $423 \pm 2^{d}$ & $0.59 \pm 0.48^{\mathrm{e}}$ & $0.84 \pm 0.13^{\mathrm{e}}$ \\
\hline Olefins & $65-89(24)$ & 836 (1089) & $19.0 \pm 11.7$ & $41.6 \pm 10.2$ & $0.56 \pm 0.50$ & $0.74 \pm 0.05$ \\
\hline Methanol & $76,83-86(5)$ & $154(195)$ & $16.5 \pm 3.7$ & $19.7 \pm 3.4$ & $0.41 \pm 0.20$ & $0.67 \pm 0.12^{\mathrm{f}}$ \\
\hline Benzene & $72-74,76-78(6)$ & $113(140)$ & $1.3 \pm 0.3$ & $1.4 \pm 0.3$ & $0.11 \pm 0.04$ & $0.14 \pm 0.05$ \\
\hline Toluene & $68-74,76-78,81-86(16)$ & $464(619)$ & $6.8 \pm 1.8$ & $9.6 \pm 0.7$ & $0.85 \pm 0.67$ & $1.36 \pm 0.27^{\mathrm{f}}$ \\
\hline $\mathrm{C}_{2}$-benzenes & $68-72,76-78,81-86(14)$ & $386(554)$ & $3.5 \pm 1.2$ & $5.5 \pm 0.5$ & $0.37 \pm 0.25$ & $0.47 \pm 0.11$ \\
\hline
\end{tabular}

a Days of the year when measurements were performed. Numbers in parenthesis indicate the number of measured days.

b Number of periods in which the flux quality criteria were met. Numbers in parenthesis correspond to the total number of 30 min periods measured.

$\mathrm{c}$ The numbers at the right of the \pm symbol indicate one standard deviation.

${ }^{\mathrm{d}}$ Units in (ppm).

e Units in $\left(\mathrm{mg} \mathrm{m}^{-2} \mathrm{~s}^{-1}\right)$.

f 10 a.m. -6 p.m. mean flux.

of building material, density, and height. The aerodynamic surface roughness was estimated to be $\mathrm{z}_{o}=1 \mathrm{~m}$ and the zero displacement plane was calculated to be $8.4 \mathrm{~m}$ height following the rule-of-thumb estimate, where $z_{d}=0.7 z_{h}$ (Grimmond and Oke, 1999).

The predominant land use is residential and commercial, with buildings of three and four stories height (most of them built of concrete with flat roofs), and roadways of one and two lanes everywhere, including 5 main avenues of up to 6 lanes as shown in the aerial photograph in Fig. 1. During daytime, convective conditions, the built up area represents $57 \%$ of the observed footprint, other impervious surfaces account for $37 \%$ and vegetation covers the remaining $6 \%$. This means that the biomass within the daytime footprint is scarce and the potential for $\mathrm{CO}_{2}$ uptake from vegetation and for biogenic VOC emissions is small. In contrast, the number of VOCs and $\mathrm{CO}_{2}$ anthropogenic sources is large, and composed of a mix of commercial, residential and mobile sources. For some nocturnal periods the footprint extended over a large forested park located northwest of the tower; however no evidence of $\mathrm{CO}_{2}$ respiration from plants was observed.

The $\mathrm{CO}_{2}$, olefin and energy flux measurements were performed continuously during 24 days in March 2006. The PTR-MS was operated for 16 days, and fluxes of methanol, benzene, toluene and $\mathrm{C}_{2}$-benzenes were measured only on selected days. Table 1 shows the days for which each compound was measured, and the total number of 30-min measurement periods. The number of periods in which benzene was measured was too small to obtain a clear diurnal flux pattern. However, the measured benzene fluxes were used to investigate benzene sources by analyzing the benzene ratio with $\mathrm{CO}_{2}$ and toluene.

March is one of the warmest months of the year in Mexico City with mean minimum and maximum temperatures of $7.7^{\circ} \mathrm{C}$ and $24^{\circ} \mathrm{C}$, respectively, and average monthly precipitation rate of $9.3 \mathrm{~mm}$ of rain. The first two weeks of the study were characterized by mostly sunny and dry conditions, while the latter portion was affected by the passage of three cold fronts, which increased the humidity and decreased the atmospheric stability, leading to increased convection and afternoon precipitation (Fast et al., 2007). In general, the meteorological conditions enhanced the VOC fluxes due to evaporative processes, and were favorable to episodes of photochemical pollution.

\subsection{Instrumentation}

A three-dimensional (3-D) sonic anemometer (Applied Technologies, Inc., model SATI-3K) and an IRGA were mounted at the top of the tower at the end of a $3 \mathrm{~m}$ boom. The length of the boom was enough to minimize the effect of flow distortion from the tower, and the sensors were arranged to be as aerodynamic as feasible. Signal/power cables were run from the sensors to a shelter on the roof-top where a pc data acquisition system was operated using LabView software specifically designed for this experiment. A Teflon sampling line (5/8 inch O.D.) was positioned from the boom down the tower to a large pump (60 slpm). Inlet lines to the FOS and PTR-MS were connected to the sampling line near the rooftop instrument shelter. The lag times for sampling at the shelter were determined from covariance analysis between the vertical wind speed and raw data from the FOS and PTRMS. The covariance was calculated for 0 to $12 \mathrm{~s}$ lags; for the FOS, $60 \%$ of the maximum correlations occurred between 2.7 and $3.8 \mathrm{~s}$, with the highest frequency occurring at $3.4 \mathrm{~s}$, while for the PTR-MS the maximum correlation occurred at $5.4 \mathrm{~s}$. The flux system collected data at $10 \mathrm{~Hz}$, and the turbulence data were used to calculate 30-min average fluxes.

The open-path IRGA has been demonstrated to be a suitable instrument for fast response measurements of water vapor and $\mathrm{CO}_{2}$ fluctuations (Pressley et al., 2005). We used the OP-2 IRGA built by ADC BioScientific and developed by the Atmospheric Turbulence and Diffusion Division (ATDD) of the National Oceanic and Atmospheric Administration 


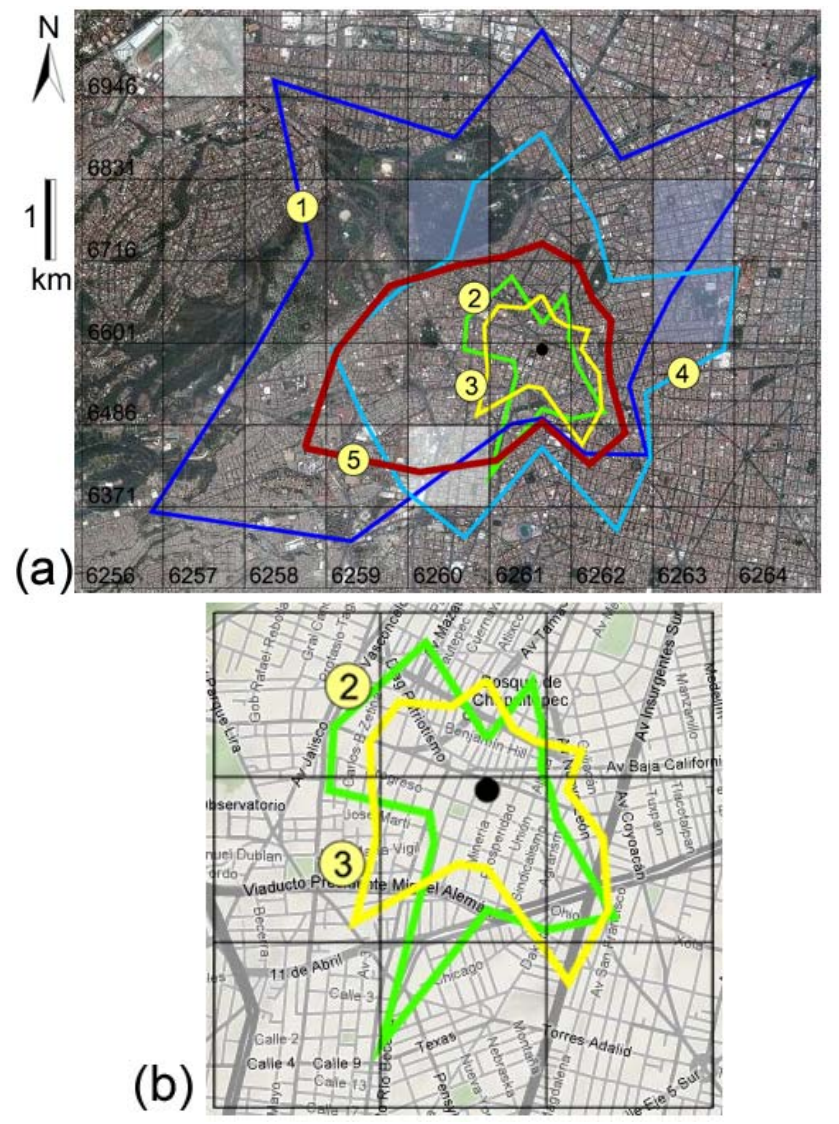

Fig. 1. Footprints encompassing $80 \%$ of the measured flux during the entire study as a function of the wind direction for different intervals of the day: (1) from midnight to 6 a.m., (2) from 6 a.m. to 12 p.m., (3) from 12 p.m. to 6 p.m., and (4) from 6 p.m. to midnight. The footprint number (5) corresponds to the average footprint for the entire set of measured periods. (a) The footprints are plotted over an aerial photograph of the study area including the $1 \times 1 \mathrm{~km}$ grid cells of the emissions inventory. The reference numbers on the left and bottom correspond to the cells numeration in the emissions inventory. The lightly shaded gray cells are cells with suspicious emissions during daytime in the emissions inventory, while the darker blue shaded cells represent suspicious emissions during nighttime. (b) Zoom of the daytime footprints superimposed on a map of the study area. Both, the aerial photograph and the map were taken from Google-Maps ${ }^{(C)}$.

(NOAA) (Auble and Meyers, 1992). Noise levels for $\mathrm{H}_{2} \mathrm{O}$ and $\mathrm{CO}_{2}$ are less than $3 \mathrm{mg} \mathrm{m}^{-3}$ and $0.03 \mathrm{mg} \mathrm{m}^{-3}$, respectively. These levels are much lower than the observed variations in the atmosphere of Mexico City; during our observations the standard deviation of $\mathrm{H}_{2} \mathrm{O}$ and $\mathrm{CO}_{2}$ mixing ratios on a $30 \mathrm{~min}$ basis were $2.6 \mathrm{~g} \mathrm{~m}^{-3}$ and $51 \mathrm{mg} \mathrm{m}^{-3}$, respectively. The $\mathrm{CO}_{2}$ response of the open-path IRGA was dynamically calibrated with a closed-path IRGA (LI6262, Licor) connected at the sampling line in the instrument shelter. The closed-path IRGA was calibrated periodically with two stan- dard gas mixtures (Scott-Marrin Inc. 331 and $430 \mathrm{ppmv}$, National Institute of Standards and Technology). The openpath IRGA was also calibrated at the start and at the end of the field campaign with the same standard gases. The openpath IRGA response to the water vapor was calibrated with the humidity data measured by a weather sensor (Vaisala, WXT510) operated at the top of the tower.

The FOS is a Fast Isoprene Sensor (Hills Scientific, Inc.; Guenther and Hills, 1998) calibrated with propylene, instead of isoprene. During the 2006 campaign the FOS was calibrated 3 times per day using propylene as the standard (Scott Specialty Gases, 10.2 ppmv, $\pm 5 \%$ certified accuracy). During the MCMA-2003 field campaign, we demonstrated the FOS applicability as an urban olefin sensor for flux measurements (Velasco et al., 2007). It has the advantage that its response time is fast enough $(10 \mathrm{~Hz})$ to measure turbulent fluxes by the conventional EC method, but the drawback is the response is not specific for any single olefin. In an urban atmosphere where numerous olefins are present, the variability in the response introduces uncertainty in the interpretation of the FOS signal. For the 2003 measurements, we tested the response for six urban species that may contribute significantly to the FOS signal. Table 2 summarizes the response of these species along with their corresponding relative sensitivity to propylene. We also compared the FOS signal with speciated alkene ambient concentrations obtained from canister samples (Velasco et al., 2007). We found that the sum of the identified olefins from canister samples represents $48 \%$ of the total olefins detected by the FOS. Recent photochemical modeling results for Mexico City have shown that the total olefins measured by the FOS correlates well in terms of magnitude and diurnal distribution with the modeled olefins considering an adjustment factor of 2.08 due to the FOS response (Lei et al., 2009).

The PTR-MS is a more specific sensor compared to the FOS. It is capable of selective and fast-response measurements of a subset of important VOCs, including aromatic and oxygenated species (Lindinger et al., 1998; de Gouw and Warneke, 2007). We used a commercial PTR-MS (IONICON Analytik $\mathrm{GmbH}$ ) for this study. The species targeted were methanol $(\mathrm{m} / \mathrm{z} 33)$, benzene $(\mathrm{m} / \mathrm{z} 79)$, toluene $(\mathrm{m} / \mathrm{z}$ 93 ) and $\mathrm{C}_{2}$-benzenes $(\mathrm{m} / \mathrm{z} 107$, including ethylbenzene, the three xylene isomers, and benzaldehyde). The meteorological raw data and the data from the PTR-MS were continuously synchronized using a flag sent by the PTR-MS acquisition system. The PTR-MS was calibrated every 2-3 days using a multi-component gas standard containing the species reported here. The standard was diluted with humidified zero air in order to generate a multipoint calibration curve from 1 to 50 ppbv. The instrument background was automatically recorded approximately twice each day by switching the sample flow to a humid zero air stream. Zero air was continuously generated by passing ambient air through a Ptcatalyst trap heated to $300^{\circ} \mathrm{C}$. Background count rates were subtracted from the ambient data. 
Table 2. Sensitivities and relative sensitivities to propylene for the FOS.

\begin{tabular}{lcc}
\hline Olefin Specie & $\begin{array}{c}\text { Sensitivity (photons } \\
\left.\mathrm{ppb}^{-1} \mathrm{~s}^{-1}\right)\end{array}$ & $\begin{array}{c}\text { Relative sensitivity } \\
\text { to propylene }\end{array}$ \\
\hline propylene & 25.4 & 1.00 \\
1-butene $^{\mathrm{a}}$ & 7.9 & 0.31 \\
3-methyl-1-butene $^{\mathrm{b}}$ & 7.9 & 0.31 \\
isobutene $^{b}$ & 7.9 & 0.31 \\
2-methyl-1-butene $^{\mathrm{b}}$ & 7.9 & 0.31 \\
trans-2-butene $^{\mathrm{b}}$ & 7.9 & 0.31 \\
Cis-2-butene $^{\mathrm{b}}$ & 7.9 & 0.31 \\
2-methyl-2-butene $^{\mathrm{b}}$ & 7.9 & 0.31 \\
1,3-butadiene $^{\text {isoprene }}$ & 49.8 & 1.96 \\
ethylene & 74.7 & 2.94 \\
NO & 17.7 & 0.70 \\
\hline
\end{tabular}

${ }^{\text {a }}$ Relative sensitivity $=($ compound sensitivity $) /($ propylene sensitivity $)$

$\mathrm{b}$ The 1-butene sensitivity factor is assigned to these species because of their similar chemical structure.

\subsection{Eddy covariance flux techniques}

\subsubsection{Conventional eddy covariance technique (EC)}

The most direct surface layer flux measurement technique is the eddy covariance method, in which the flux of a trace gas $\left(F_{\chi}\right)$ is calculated as the covariance between the instantaneous deviation of the vertical wind velocity $\left(w^{\prime}\right)$ and the instantaneous deviation of the trace gas $\left(c_{\chi}^{\prime}\right)$ from their $30 \mathrm{~min}$ mean:

$F_{\chi}=\overline{w^{\prime} c_{\chi}^{\prime}}=\frac{1}{N} \sum_{i=1}^{N} w^{\prime}\left(t_{i}\right) c^{\prime}\left(t_{i}\right)$

where the over-bar denotes a time-averaged quantity. Fundamental aspects of EC have been widely discussed elsewhere (e.g., McMillen, 1988; Aubinet et al., 2000). We followed the same post-processing steps as described previously in Velasco et al. (2005a, b). The fluxes were corrected for the effects of the air density using the Webb correction, a coordinate rotation on 3-D velocity components was performed to eliminate errors due to sensors tilt relative to the surface, and a low pass filter was applied to eliminate the presence of a possible trend in the 30-min series.

\subsubsection{Virtual disjunct eddy covariance technique (DEC)}

The PTR-MS was operated in a selective ion mode measuring up to 4 compounds of interest with a variable resolution time between 0.2 and $0.5 \mathrm{~s}$ depending on the number of analyzed species, since they are not measured simultaneously. This produces a discontinuous time-series, and requires matching concentration measurements with the associated $10 \mathrm{~Hz}$ wind data from the sonic anemometer. This process is known as virtual DEC (Karl et al., 2002).
The raw data to calculate the DEC fluxes are postprocessed following the same equation (1) and steps for the conventional EC. The only difference between the two techniques is the reduced number of data points used for the flux calculation, which results in an increase in the statistical uncertainty of the fluxes.

Turnipseed et al. (2009) and Amman et al. (2006) have validated the DEC technique coupled with PTR-MS by parallel EC flux measurements. Turnipseed et al. (2009) measured in parallel EC fluxes of isoprene using a Fast Isoprene Sensor while Amman et al. (2006) fluxes of water vapor using an IRGA. With the 2003 data, we evaluated the statistical uncertainty of the fluxes processed by DEC by recalculating the olefin and sensible heat flux for the entire MCMA-2003 campaign from the $10-\mathrm{Hz}$ raw data using different sample intervals up to $3.6 \mathrm{~s}$. The DEC fluxes were compared with the fluxes calculated by EC: there is good agreement for sensible heat flux with a correlation coefficient of 0.99 and slope of 1.00 for all sampling intervals; however, for olefins, there is a clear difference when the sampling interval was greater than $1.2 \mathrm{~s}$. It seems that the origin, mixing and reactivity of the anthropogenic VOCs in the atmosphere affect the integral timescale for DEC measurements. Assuming similar behavior between the olefin flux and the fluxes of the species measured by the PTR-MS, the potential error due to the DEC statistical uncertainties was calculated to be $\sim 9 \%$. This error can be reduced by making the time step between samples shorter or by using a longer averaging time.

\subsection{Quality of the flux measurements}

The quality of flux measurements is difficult to assess because there are various sources of errors. Conflicts with the assumptions of the EC technique to estimate fluxes arise under certain meteorological conditions and site properties. As these effects cannot be quantified solely from EC data, a classical error analysis and error propagation will remain incomplete. Instead, Aubinet et al. (2000) suggest using an empirical approach to determine whether the fluxes meet certain plausibility criteria. Besides the statistical characteristics of the raw instantaneous measurements, we investigated the frequency resolution of the EC system through the spectra and cospectra of the measured variables, and through the stationarity of the eddy flux process.

\subsubsection{Spectral and cospectral analysis}

An EC system attenuates the true turbulent signal at sufficiently high and low frequencies due to limitations imposed by the physical size of the instruments, their separation distances, their inherent time response, and any signal processing associated with detrending or mean removal (Massman and Lee, 2002). Inspection of the spectra and cospectra of the measured variables helps to determine the influence of these attenuations. For our flux measurements, we evaluated 
the spectra of the ambient temperature, $\mathrm{CO}_{2}$ and olefin concentrations, as well as the cospectra between these variables and $w$ with a standard fast Fourier transform routine. As expected, the ambient temperature and sensible heat show the best agreement with the theoretical frequency distribution, showing the characteristic $-5 / 3$ and $-7 / 3$ slopes for spectra and cospectra, respectively, in the inertial subrange, which is the range where the net energy coming from the energy-containing eddies is in equilibrium with the net energy cascading to smaller scales where it is dissipated (Roth, 2000). The inertial subrange for $\mathrm{CO}_{2}$ and olefins concentrations, as well as for the cospectra of both compounds and $w$ was shifted to lower frequencies. For the olefin measurements this frequency attenuation was enhanced by the damping of fluctuations within the sampling tube and instrument response time. This lack of high frequency contribution was addressed using a low-pass filtered heat flux as proposed by Massman and Lee (2002). The discontinuous time-series of the species measured by the PTR-MS did not allow for a spectra and cospectral evaluation. However, the same spectral correction was applied also to them, assuming a similar loss of flux at high frequency for both FOS and PTR-MS.

As described in the 2003 flux measurements, the 2006 spectra and cospectra results show that our flux system is capable of measuring turbulence fluxes of trace gases via the conventional EC mode in an urban environment. However, sampling periods that did not fulfill the stationarity requirements (described below) generally did not meet the spectral and cospectral analysis criteria. Those sampling periods were not omitted from further analysis based on the spectral and cospectral analysis, but they were discarded based on the stationarity test which is easier to apply objectively.

\subsubsection{Stationarity evaluation}

The applicability of an urban flux tower is confined to stationarity conditions, such that the measurement height exceeds the blending height at which the small-scale heterogeneity merges into a net exchange flux above the city. One criterion for stationarity is to determine if the difference between the flux obtained from a 30-min average and the average of fluxes from six continuous subperiods of 5 min during the same 30-min period is less than $60 \%$ (Aubinet et al., 2000). If the difference is less than $30 \%$, the data are considered high quality; and between 30 and $60 \%$, the data are acceptable. When the difference is greater than $60 \%$ the flux is removed from subsequent analyses. In our study, the stationarity condition was fulfilled in more than $70 \%$ of the $30-\mathrm{min}$ periods for all the species measured. Table 3 summarizes the results of the stationarity test, including the species measured by the PTR-MS. Conditions of non-stationarity were related to very unstable and stable atmospheric conditions. These results are similar to those observed during the 2003 flux measurements.
Table 3. Percent of periods that met the stationarity conditions for each one of the measured species. If the difference between the 30min flux and the average flux of 6 continuous subperiods of 5 min from that same period of $30 \mathrm{~min}$ is less than $30 \%$, the data is considered of high quality, and between 30 and $60 \%$, the data have an acceptable quality.

\begin{tabular}{lll}
\hline & $<30 \%(\%)$ & $<60 \%(\%)$ \\
\hline $\mathrm{CO}_{2}$ & 69 & 85 \\
Olefins & 57 & 77 \\
methanol (m33) & 55 & 79 \\
benzene (m79) & 59 & 81 \\
toluene (m93) & 54 & 75 \\
$\mathrm{C}_{2}$-benzenes (m107) & 47 & 70 \\
\hline
\end{tabular}

\subsection{Footprint analysis}

The height of the tower, together with the surface roughness, canopy structure, wind speed and direction, and atmospheric stability determine the footprint of the measured flux. Specifically, the footprint indicates the fraction of the surface (usually upwind) containing effective sources and sinks that contribute to the vertical flux measured (Vesala et al., 2008). To evaluate the footprint we used an analytical model based on Lagrangian dispersion modeling and dimensional analysis proposed by Hsieh et al. (2000) with the previously estimated zero plane displacement and an assumed roughness height of $1 \mathrm{~m}$. We applied this model to the complete set of 30-min periods measured during the campaign to determine the fraction of the flux measured $\left(F / S_{0}\right)$ as a function of the upwind distance and the atmospheric stability condition. $F$ represents the flux and $S_{0}$ the source strength. If the footprint is defined to encompass $80 \%$ of the total flux, the longest footprint $(6.8 \mathrm{~km})$ was observed during stable atmospheric conditions, which prevail at nighttime; while the shortest footprint $(650 \mathrm{~m})$ occurred during daytime unstable conditions. On average the estimated footprint was $1150 \mathrm{~m}$ during the entire campaign covering an area of $7.6 \mathrm{~km}^{2}$, which represents an area large enough to characterize the fluxes of $\mathrm{CO}_{2}$ and VOCs of a typical district of Mexico City. Figure 1 shows the footprint fractions estimated throughout the course of the day in periods of $6 \mathrm{~h}$. The footprint extended over an area of $24 \mathrm{~km}^{2}$ at night and $1.5 \mathrm{~km}^{2}$ during daytime. Generally, the daytime footprint extended homogeneously in all directions; only during early morning was the footprint from the southeast direction reduced. In general, the footprint size of this second flux tower was very similar to the footprint observed for the 37-m flux tower used in 2003. 


\section{Results}

\subsection{Ambient concentrations}

As expected, the compounds analyzed show a distinct diurnal pattern with maximum concentrations during the morning rush-hour period and minimum concentrations during the afternoon (see Fig. 2). The ambient concentrations increase sharply at 6 a.m., when the vehicular traffic begins. From 6 to 9 a.m. with a slowly growing boundary layer and weak photochemical activity, concentrations of primary pollutants reach maximum levels. After this period, the concentrations of the primary pollutants decrease due to dilution within the growing boundary layer and photochemical reactions. At sunset, the development of a new nocturnal stable boundary layer enhances the accumulation of pollutants from the evening rush hour. A detailed description of the diurnal VOCs pattern in the atmosphere of Mexico City is provided by Velasco et al. (2007). The only exception to this description is methanol, which does not decrease substantially during the day, suggesting a strong secondary formation during the day or the mixing with air aloft enriched in methanol. Methanol has a long life time; consequently, emissions from biogenic and biomass burning sources outside of the city, both primary and secondary from oxidation processes may also be significant contributors (Jacob et al., 2005; Holzinger et al., 2005).

In general, the diurnal patterns of the species measured were relatively constant during the entire field campaign. Table 1 shows the 24-h median concentrations and the median concentrations measured during the morning rush-hour period (6-9 a.m.). Although the number of monitored weekends was small (3), we found that the highest concentrations were observed on Saturdays, while the lowest concentrations occurred on Sundays. An interesting feature is that the early morning concentrations on Saturdays and Sundays were consistently higher than on weekdays. This effect has been observed also in the local air quality monitoring network for the ambient concentrations of $\mathrm{CO}$ and $\mathrm{NO}_{\mathrm{x}}$ (Stephens et al., 2008), and it has been called the "party effect" because of its origin from the abundant social and entertainment activities during Friday and Saturday nights, which yield higher traffic levels.

As shown in Fig. 2, the diurnal distributions observed in 2003 were similar to those observed in 2006. In terms of magnitudes, the 2003 concentrations of the analyzed species were mostly within the one standard deviation range of the 2006 concentrations, except $\mathrm{CO}_{2}$, which showed much lower concentrations in 2003 for all hours of the day except the morning rush hour. On average the $\mathrm{CO}_{2}$ difference between the two campaigns was 22 ppmv. As noted in the next section, the $\mathrm{CO}_{2}$ fluxes in 2003 and 2006 were quite similar which suggests that the concentration differences were due to differences in $\mathrm{CO}_{2}$ background concentrations between the two sites and the two different years.

\subsection{Fluxes}

\subsubsection{Diurnal patterns}

As shown in Fig. 3, the fluxes of the species analyzed were always positive on a diurnal average basis which indicates that the urban surface is always a net source. The highest fluxes occurred during daytime and the lowest during the night. In contrast to the ambient concentration profiles, which depend on emissions, deposition, and chemical and meteorological processes, the flux profiles depend primarily upon deposition and emission rates from the underlying surface. Due to the urban location, emissions are predominantly from anthropogenic activities. As described previously, biogenic sources were insignificant because of the scarce vegetation within the monitored footprint. In particular, for the olefin fluxes, no correlations with temperature or solar radiation were observed. In the same context, the $\mathrm{CO}_{2}$ uptake by the urban vegetation was not strong enough to offset the $\mathrm{CO}_{2}$ flux from anthropogenic sources during daytime. Even though the footprint for some nocturnal periods extended to the Chapultepec Park located $1.4 \mathrm{~km}$ to the northwest of the tower, $\mathrm{CO}_{2}$ respiration from plants was not evident in the flux profile. This was because according to the footprint model applied, the footprint peak during stable conditions at night was located approximately $500 \mathrm{~m}$ upwind of the tower and well within the urban (non-park) landscape.

The fluxes of $\mathrm{CO}_{2}$, olefins and $\mathrm{C}_{2}$-benzenes showed similar diurnal atterns. The morning-start of the fluxes of these species occurred at 6 a.m., coinciding with the onset of the morning rush-hour period. During the rest of the morning and the first three hours of the afternoon the fluxes remained relatively constant. Table 1 shows the average of the fluxes measured between 7 a.m. and 3 p.m., as well as for the entire day.

During the rest of the afternoon and evening, the fluxes of $\mathrm{CO}_{2}$, olefins and $\mathrm{C}_{2}$-benzenes drop gradually, apparently as a consequence of a shift in the wind direction. Throughout the morning and early afternoon hours, the wind blew mostly from the WNW-ESE sector, while for the rest of the afternoon winds blew from the ESE-SSE sector or the NW. Considering the entire diurnal course, the fluxes coming from the SE-SW sector were consistently lower than the fluxes coming from the rest of the wind rose, as shown for $\mathrm{CO}_{2}$ fluxes in Fig. 4. This suggests a difference in the distribution of the emission sources within the footprint. The number of avenues with heavy traffic is higher in the WNW-ESE sector than in the SE-SW sector as shown in Fig. $1 b$.

The fluxes of toluene and methanol showed a different diurnal pattern compared to the pattern for $\mathrm{CO}_{2}$, olefins and $\mathrm{C}_{2}$-benzenes. The fluxes of these two species show two increments during the morning: the first occurs at the beginning of the morning rush-hour period, and the second occurs at approximately 9:30 a.m. In the first increment, methanol and toluene fluxes increase by a factor of $\sim 1.7$, while in the 

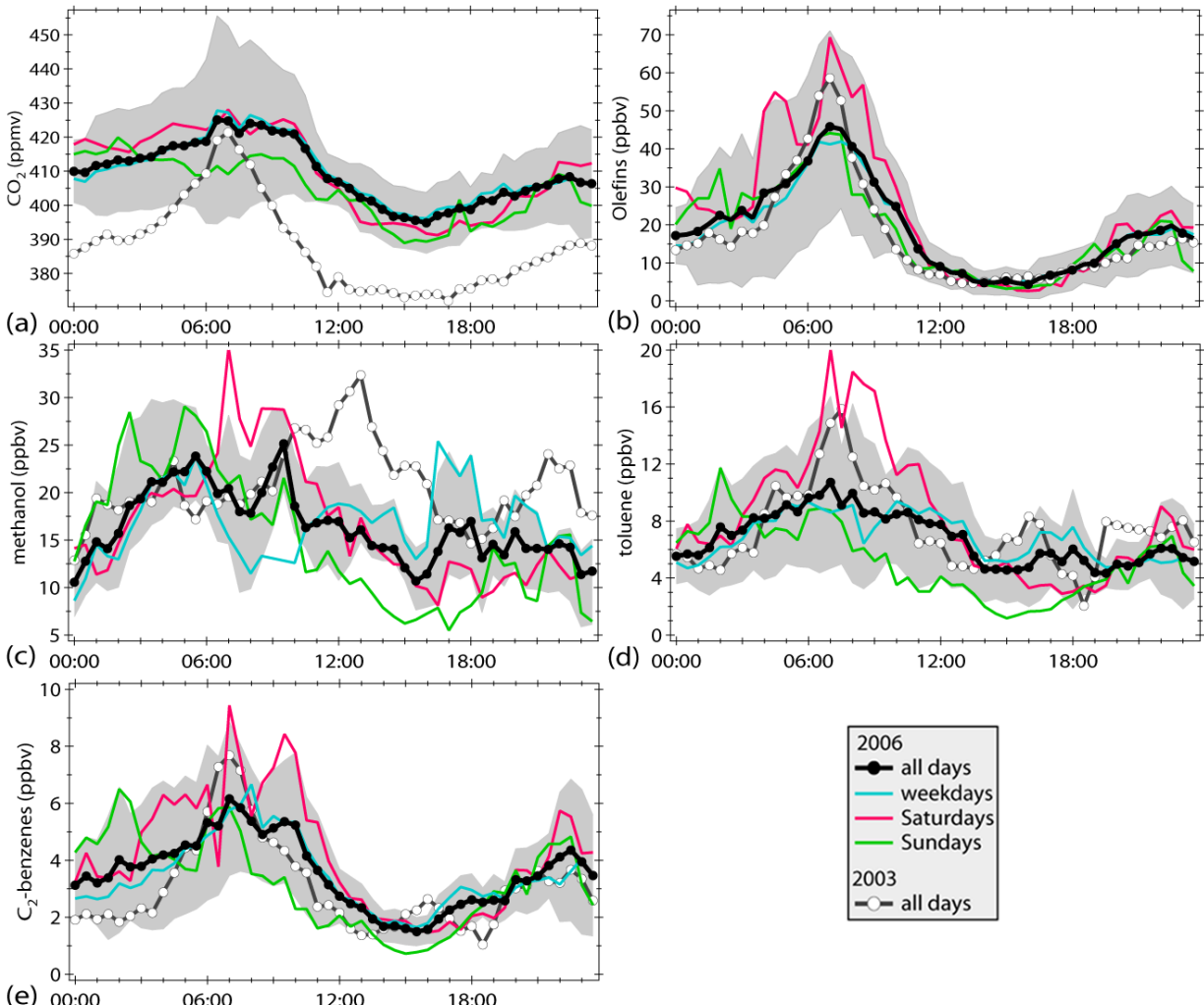

(d) 00:00

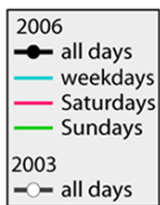

(e) $00: 00$

Fig. 2. Average diurnal patterns of ambient concentrations of (a) $\mathrm{CO}_{2}$, (b) mix of olefinic VOCs detected by the FOS, (c) methanol, (d) toluene, and (e) $\mathrm{C}_{2}$-benzenes for the entire study, weekdays, Saturdays and Sundays. The ambient concentrations measured in 2003 at the CENICA site are included as reference. The grey shadows represent \pm 1 standard deviation from the total 2006 averages, and give an indication of the day-to-day variability in each phase of the daily cycle. The time scale corresponds to the local standard time.

second increment, fluxes increase by a factor of $\sim 2.2$. The second peak at 9:30 a.m. is attributed to the beginning of commercial painting and other solvent uses. Subsequently, the fluxes remain high and constant until 6 p.m. Table 1 shows the average fluxes for this period and for the entire day. For the rest of the day and night, toluene and methanol fluxes decrease to low levels.

In terms of day of the week, the highest fluxes were observed on weekdays, and the lowest on Sundays. Table 4 shows the ratios between the fluxes measured on Saturdays and Sundays with the fluxes measured on weekdays for different periods of the day. Fluxes on Saturdays were between $13 \%$ and $24 \%$ lower than during weekdays, while on Sundays the fluxes of $\mathrm{CO}_{2}$, olefins and $\mathrm{C}_{2}$-benzenes were between $33 \%$ and $54 \%$ lower, and the fluxes of toluene and methanol were $\sim 66 \%$ lower. The "party effect" was clearly observed in the early morning fluxes of $\mathrm{CO}_{2}$, olefins and $\mathrm{C}_{2}$-benzenes, which were $25 \%$ higher between midnight and 6 a.m. on weekends than on weekdays. This nighttime increase was not observed for toluene and methanol fluxes. On Saturdays during the morning and early afternoon, the fluxes of toluene and methanol were similar or higher than those on weekdays.
The 2006 fluxes of VOCs and $\mathrm{CO}_{2}$ show similar diurnal profiles to those observed in 2003 , but with higher magnitudes. The fluxes of $\mathrm{CO}_{2}$ and olefins were 1.4 and 1.5 times higher, respectively in 2006 than in 2003, mainly because traffic levels are higher near the 2006 site compared to the 2003 site. The number of congested roadways within the observed footprint in 2006 was at least twice as many as for the 2003 location. The fluxes of methanol and toluene were 2.6 and 1.7 times higher, respectively. We believe this was also due to differences in anthropogenic activities in the two neighborhoods. The $\mathrm{C}_{2}$-benzenes fluxes measured in 2006 were 2.6 times higher than those measured in 2003, thus we expected to find a similar relationship for $\mathrm{CO}_{2}$ and olefins, since $\mathrm{C}_{2}$-benzenes emissions also come from vehicular combustion. An interesting feature in the 2003 flux profiles was a spike in the olefins flux during the morning rush-hour period. This spike was not observed in the olefins flux measured in 2006, nor in the fluxes of the other species measured in both years. This spike might arise from other local sources different than vehicle exhaust.

The spatial variability of VOC emissions within Mexico City was evaluated during the MILAGRO field campaign by DEC flux measurements of toluene and benzene from an 

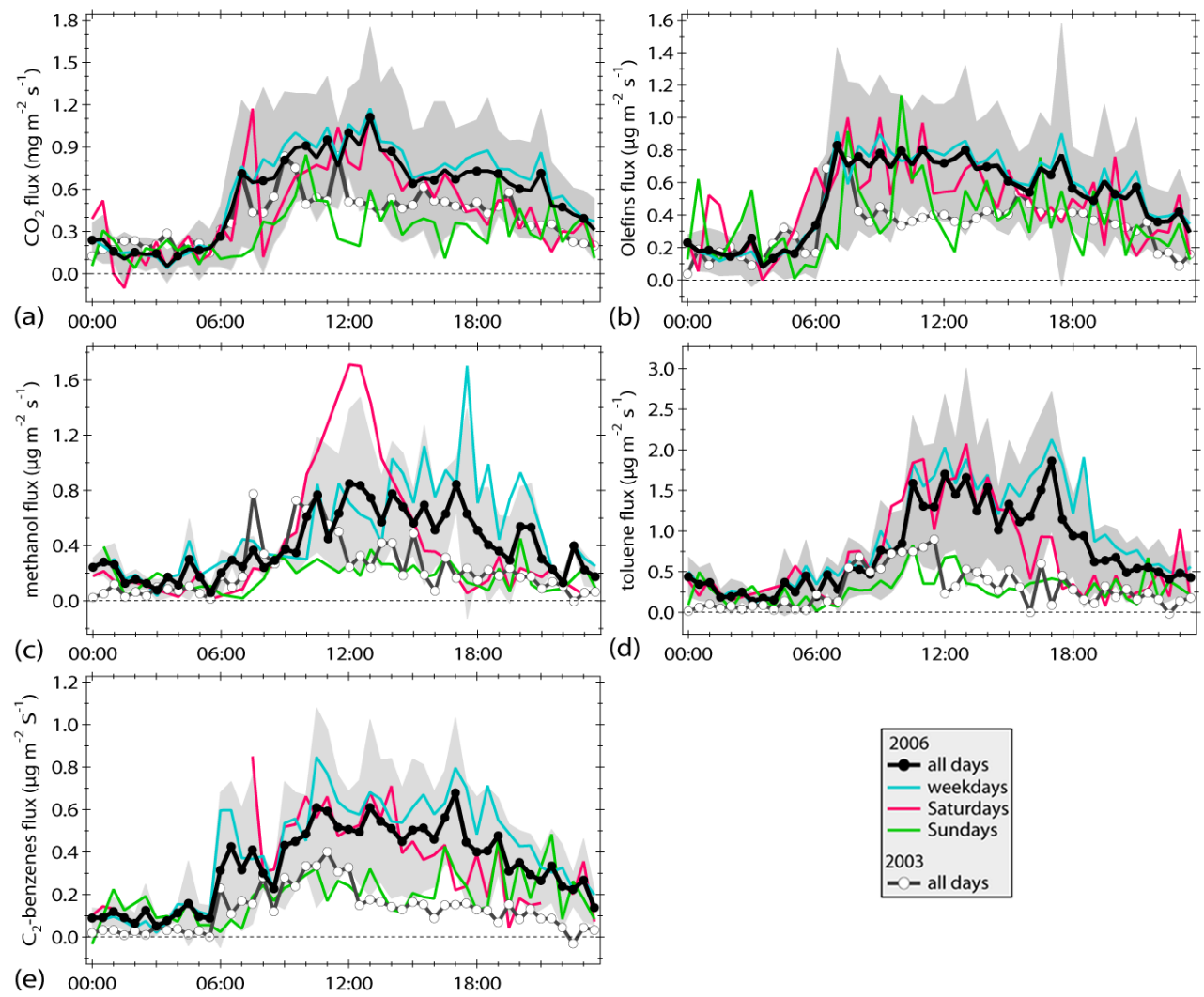

(e) $00: 00$

6:00

Fig. 3. Average diurnal patterns of the flux of (a) $\mathrm{CO}_{2}$, (b) mix of olefinic VOCs as propylene detected by the FOS, (c) methanol, (d) toluene, and (e) $\mathrm{C}_{2}$-benzenes for the entire study, weekdays, Saturdays and Sundays. The fluxes measured in 2003 at the CENICA site are included as reference. The grey shadows represent \pm 1 standard deviation from the total 2006 averages, and give an indication of the day-to-day variability in each phase of the daily cycle. The time scale corresponds to the local standard time.

Table 4. Ratios between the fluxes measured on Saturdays and Sundays and the fluxes measured on weekdays for different periods of the day.

\begin{tabular}{llllllllllll}
\hline & \multicolumn{2}{c}{$\mathrm{CO}_{2}$} & \multicolumn{2}{c}{ Olefins } & \multicolumn{2}{c}{$\mathrm{C}_{2}$-benzenes } & \multicolumn{2}{c}{ Toluene } & \multicolumn{3}{c}{ Methanol } \\
\hline & Sat. & Sun. & Sat. & Sun. & Sat. & Sun. & Sat. & Sun. & Sat. & Sun. \\
All day & 0.76 & 0.49 & 0.87 & 0.67 & 0.86 & 0.46 & 0.80 & 0.32 & 0.78 & 0.35 \\
0-6 a.m. & 1.05 & 1.11 & 1.48 & 1.33 & 1.28 & 1.16 & 1.04 & 0.62 & 0.62 & 0.66 \\
6 a.m.-3 p.m. & 0.82 & 0.43 & 0.89 & 0.61 & 0.94 & 0.35 & 1.03 & 0.30 & 1.41 & 0.39 \\
3 p.m.-12 a.m. & 0.62 & 0.49 & 0.73 & 0.63 & 0.55 & 0.49 & 0.40 & 0.28 & 0.34 & 0.25 \\
10 a.m.-3 p.m. & & & & & & & 1.00 & 0.29 & 1.78 & 0.38 \\
\hline
\end{tabular}

aircraft platform (Karl et al., 2009). These flights were carried out across the northeast section of the city where the industrial district and the airport are located. For these locations, fluxes of toluene above $12 \mu \mathrm{g} \mathrm{m}^{-2} \mathrm{~s}^{-1}$ were observed, with a median flux of $3.9 \pm 1.1 \mu \mathrm{g} \mathrm{m}^{-2} \mathrm{~s}^{-1}$ along the flight leg. This median flux is 1.3 times larger than the peak flux and 2.8 times larger than the average daytime flux observed at our ground site.

\subsubsection{Correlation between fluxes of VOCs and $\mathrm{CO}_{2}$}

Because of the close relationship between $\mathrm{CO}_{2}$ and combustion sources, comparison of the flux measurements of selected VOCs and $\mathrm{CO}_{2}$ is useful in examining the origin of those VOCs, as well as determining their emission rates in terms of the $\mathrm{CO}_{2}$ released from the urban surface. Figure 5 shows the correlations between the fluxes of the analyzed VOC species, including benzene, and $\mathrm{CO}_{2}$. It is important to point out that these correlations are not affected by 

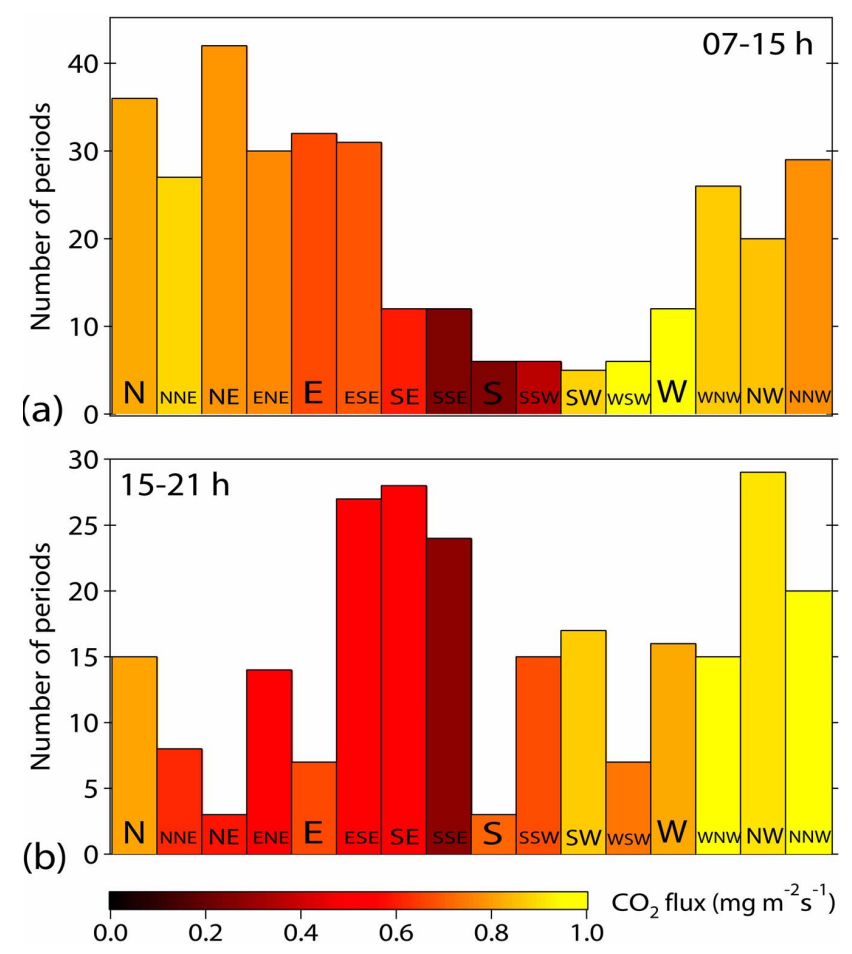

Fig. 4. Histograms of wind direction during two diurnal periods, 7 a.m. to 3 p.m. (a), and 3 p.m. to 9 p.m. (b) for the entire field campaign. The color gradient indicates the $\mathrm{CO}_{2}$ flux average for each wind direction sector and diurnal period.

photochemical aging or meteorological processes, and neglecting the human and vegetation respiration, the correlations with $\mathrm{CO}_{2}$ provide a basis for direct evaluation of the emission rates from an urban district.

In this way, we found that olefins, benzene and $\mathrm{C}_{2}$ benzenes appear to have their main origin in combustion sources. The variability on the emission ratios as a function of the period of the day shown in Fig. 5 is different for each compound, and it is also an indication of the variability of combustion sources. Benzene shows good flux correlations with $\mathrm{CO}_{2}$ throughout the day with high correlation coefficients ranging from 0.67 to 0.91 , and low variability in the ratios throughout the day. From the correlation using the entire set of data, the monitored district emits $0.16 \mu \mathrm{g}$ of benzene per mg of $\mathrm{CO}_{2}$. In the same context, $0.60 \mu \mathrm{g}$ of both olefins and $\mathrm{C}_{2}$-benzenes are emitted per mg of $\mathrm{CO}_{2}$. The emission relationship among compounds can vary considerably within the Mexican fleet, as observed during on-road VOC characterization of vehicle plumes during the MCMA-2003 field campaign (Zavala et al., 2006; Velasco et al., 2007) and MCMA-2006 (Zavala et al., 2009). This variation in the emission ratios from vehicle exhaust, in addition to evaporation from fuel tanks and engines, contributes to the scatter in the correlations between the fluxes of these species and $\mathrm{CO}_{2}$. The variations of the FOS response to different alkenes may also contribute to the scatter in the correlation between the fluxes of olefins and $\mathrm{CO}_{2}$.

The correlations between the fluxes of toluene and methanol with the fluxes of $\mathrm{CO}_{2}$ show more scatter than the correlations for the species and $\mathrm{CO}_{2}$ mentioned above. These two compounds are associated with solvent evaporation from cleaning, painting, and printing processes, as well as from application of adhesives, dyes and inks. During a portion of the field campaign, the evaporative emissions of these two species appeared to be strongly enhanced by the application of a paint resin to the sidewalks near the tower by the local district city maintenance workers. The intense fluxes of toluene and methanol appear to follow the schedule of the district workers, ending at 6 p.m. on weekdays and 3 p.m. on Saturdays. On weekdays from 9:30 a.m. to 6 p.m., the ratios between the fluxes of toluene and methanol relative to $\mathrm{CO}_{2}$ were 1.9 and 1.5 times higher, respectively, than during the rest of the day. Moreover, the flux ratio of $0.62 \mu \mathrm{g}$ of toluene per $\mathrm{mg}$ of $\mathrm{CO}_{2}$ for the rest of the day was essentially similar to the ratio (0.63) observed at the CENICA site in 2003.

To further investigate the sources of toluene, we examined the toluene to benzene ratio in terms of fluxes and ambient concentrations (see Fig. 6). Since vehicular traffic is the main source of benzene in urban environments (Fortin et al., 2005), benzene has been used as a tracer to identify VOC sources in different studies (e.g., Barletta et al., 2005; Schnitzhofer et al., 2008). From previous ambient concentration measurements, a toluene to benzene mass ratio of $4.3 \pm 2.0$ was determined for urban sites of Mexico City (Velasco et al., 2007), and a ratio of 1.9 for the Mexican fleet emissions (Zavala et al. 2006). A direct comparison between these two ratios suggests that in addition to vehicle exhaust, there are other important sources of toluene in Mexico City. For the ambient concentrations measured in 2006, a ratio of $4.8 \pm 0.3$ was found, similar to the ratio reported previously for other urban sites of the city. The neighborhood sidewalk resin application does not appear to affect the ratio for the 2006 measurements compared to the other measurements, as shown in Fig. 6a.

In contrast, the effect of the resin application is clearly observed in Fig. $6 \mathrm{~b}$ for the ratio in terms of fluxes. During the resin application, the mass ratio between fluxes was $7.0 \pm 1.2$, approximately 1.7 times higher than during the rest of the day (4.2 \pm 0.5$)$, when the ratio between fluxes was similar to the ratio observed for ambient concentrations. Karl et al. (2009) also observed the impact of evaporative emissions on the toluene to benzene ratio, for the northern industrial district they observed peak flux ratios ranging from 10 to 15 , with a mean ratio of $3.2 \pm 0.5$ along their flights.

Continuous long-path measurements of toluene and benzene by Differential Optical Absorption Spectroscopy (DOAS) have shown that photochemical aging at a local scale in Mexico City is negligible due to the direct influence of the fresh emissions on the atmospheric concentrations (Velasco et al., 2007). An alternative explanation for the 


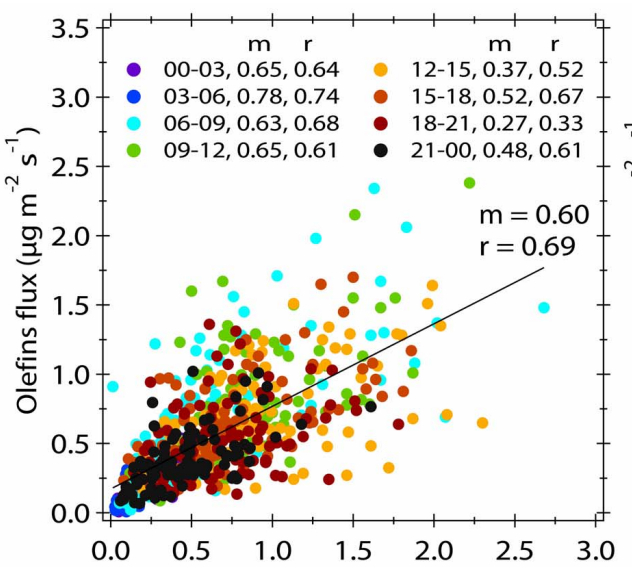

(a)
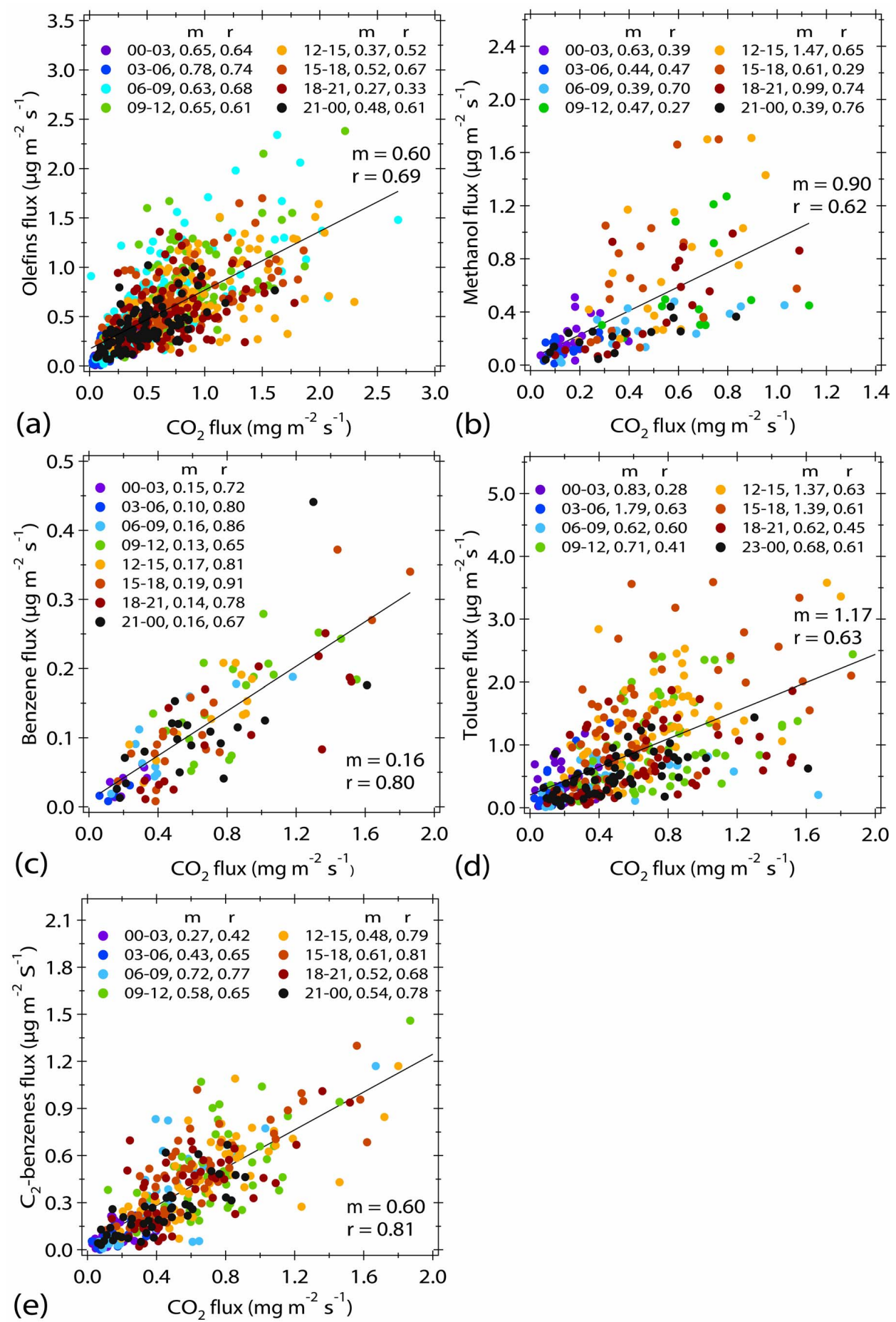

(d) $\quad \mathrm{CO}_{2}$ flux $\left(\mathrm{mg} \mathrm{m}^{-2} \mathrm{~s}^{-1}\right)$

(e)

Fig. 5. Flux correlations between $\mathrm{CO}_{2}$ and olefins (a), methanol (b), benzene (c), toluene (d), and $\mathrm{C}_{2}$-benzenes (e). The correlations were divided into bins of 3-h periods throughout the day. The ratios $(m)$ and correlation coefficients $(r)$ for each period are included in the panels. The black line indicates the regression line for all the data; their ratios and correlation coefficients are in larger fonts.

discrepancy between concentration and flux ratios of toluene to benzene may be that the footprint is larger for ambient concentrations than for fluxes, as explained by Vesala et al. (2008). These ratios used with the ratio for the Mexican vehicle fleet, suggests that $27 \%$ of the toluene flux is due to vehicle exhaust during this period, while $45 \%$ of the toluene flux appears to be linked to traffic during the rest of the day. 

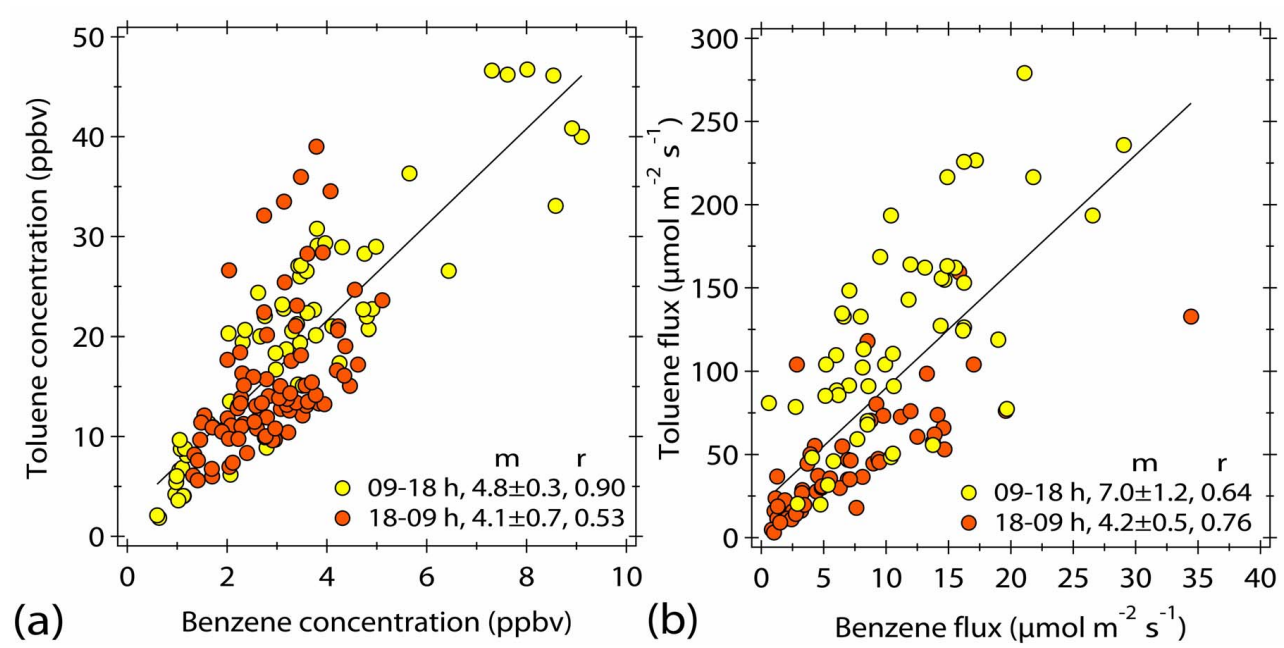

Fig. 6. Correlations between toluene and benzene for ambient concentrations (a) and fluxes (b). The correlations were calculated for two periods, one including the period of resin application to the sidewalks ( 9 a.m. to 6 p.m.), and the second for the remaining time. The black line indicates the regression line for all the data.

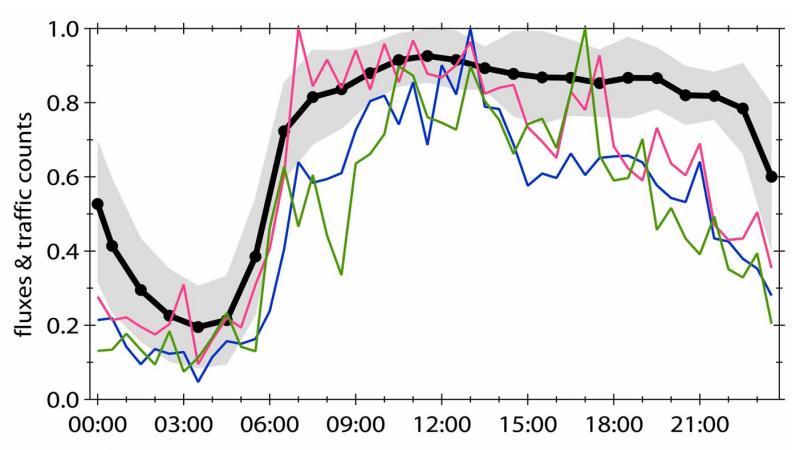

(a)

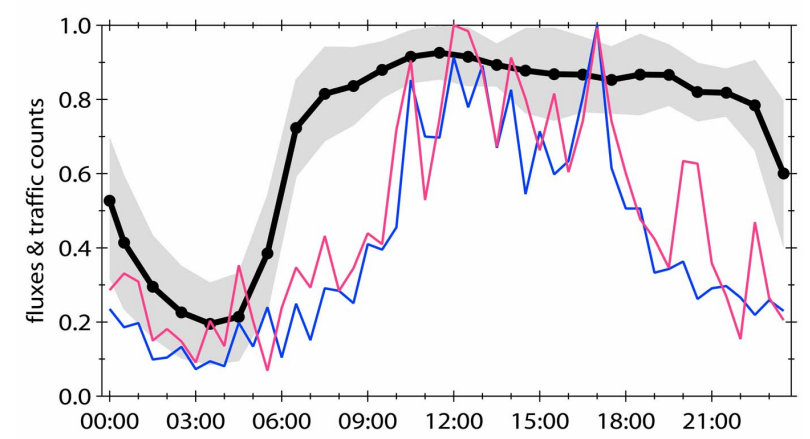

(b)

Fig. 7. Diurnal profiles of normalized traffic counts and fluxes of $\mathrm{CO}_{2}$, olefins, and $\mathrm{C}_{2}$-benzenes (a), and toluene and methanol (b). The traffic counts represent the average traffic from 11 roadways in a $10 \mathrm{~km}$ radius from the flux tower site. The gray shadow indicates \pm 1 standard deviation from the traffic counts. The time scale corresponds to the local standard time.

\subsubsection{Fluxes as a function of vehicular activity}

To evaluate the influence of the vehicular traffic on the emissions of these species we can compare flux measurements with traffic density data. For this comparison, we used traffic counts from 11 roadways in a 10-km radius from the flux tower. These traffic counts correspond to the most recent study (2003) of vehicular activity in the city carried out by the local authorities. The selected roadways are heavily traveled with traffic counts ranging from 14875 to 68171 vehicles daily. With the assumption that the diurnal traffic pattern has not changed significantly from 2003, each traffic count distribution was normalized to their maximum hourly count and the average from the 11 roadways is plotted along with the normalized fluxes in Fig. 7. The typical morning and afternoon traffic peaks are not identified, instead a single peak is observed during the entire day. This peak begins at 6 a.m., and extends until the evening. Figure $7 \mathrm{a}$ shows that the diurnal flux patterns of $\mathrm{CO}_{2}$, olefins and $\mathrm{C}_{2}$-benzenes follow the vehicular traffic profile during a large part of the day. The fluxes of these species and the traffic counts increase simultaneously during the morning rush-hour period, and stay constant for the rest of the morning. Throughout the afternoon, the fluxes of these species drop gradually, but not the vehicular traffic. As discussed previously, this afternoon decrease in fluxes is due to a change in the wind direction toward a sector with lower traffic levels.

The morning and late afternoon offsets between the normalized profiles of traffic and toluene and methanol fluxes in Fig. 7b, show the impact of the evaporative emissions from the resin applied to the sidewalks near the tower from 9 a.m. to 6 p.m. Comparison of the correlation coefficients obtained from linear regressions between traffic counts and 

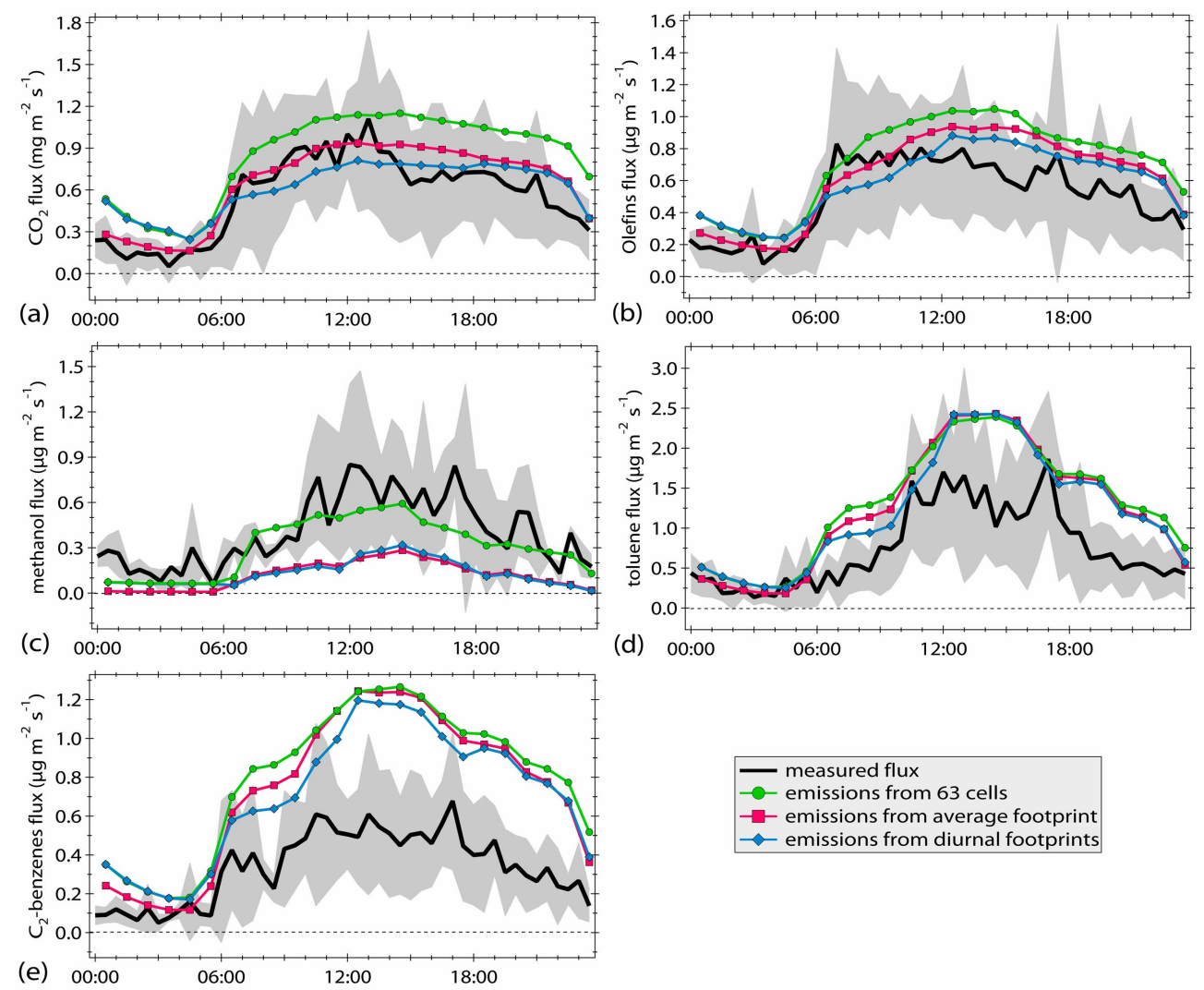

Fig. 8. Comparison of the diurnal profiles of fluxes of $\mathrm{CO}_{2}$ (a), olefins (b), methanol (c), toluene (d), and $\mathrm{C}_{2}$-benzenes (e) with the diurnal profiles of emissions from the 2006 emissions inventory. The emissions were extracted from the grid cells coinciding with the footprints described in the text and the 63 surrounding cells. The gray shadows indicate \pm 1 standard deviation of the measured fluxes.

fluxes of toluene (0.72) and methanol (0.73), with those obtained for $\mathrm{CO}_{2}(0.94)$, olefins $(0.91)$ and $\mathrm{C}_{2}$-benzenes $(0.84)$ confirms the lower vehicle exhaust contribution to toluene and methanol fluxes.

\subsection{Comparison of measured fluxes versus calculated emissions in the local emissions inventory}

A primary purpose of this work was to employ the flux data to evaluate the accuracy of the gridded emissions inventory derived for air quality modeling. To accomplish this, we compared our flux measurements to the most recent emissions inventory for Mexico City. This emissions inventory covers the entire metropolitan area in cells of $1 \mathrm{~km}^{2}$, with hourly emissions of $\mathrm{CO}_{2}$ and 552 VOC species, including other pollutants from mobile, area and point sources, using 2006 base data (SMAGDF, 2008). This inventory was created using bottom-up methods and emission factors which were either measured locally or taken from the literature. For mobile sources, the MOBILE5 emissions model was adapted to account for local vehicle characteristics, and their emissions were distributed spatially and temporally on the basis of traffic count data for primary and secondary roadways.
Emissions from area sources were obtained from geographical statistics, including population density, land use and economic level of each of the districts within the metropolitan area. Emissions from industries, workshops, and commerce and service establishments were obtained from operational permits containing information about their activities, such as processes, work hours, and location.

The $\mathrm{CO}_{2}$, olefins, toluene, $\mathrm{C}_{2}$-benzenes and methanol emissions were extracted from the grid cells coinciding with the 5 footprints shown in Fig. 1a. The four 6-h footprints were averaged to obtain more precise emission profiles throughout the diurnal course. The emissions were adjusted by the footprint fraction covered in each cell (i.e., if the footprint covered $47 \%$ of a cell, only $47 \%$ of the emissions from that cell were considered). In addition, the emissions from 63 cells around the flux tower were also extracted with the intent to analyze the homogeneity of the emissions over a wider area. Of these 63 cells, the mobile emissions from five cells appear to be incorrect. Three of them report very high emissions at nighttime, and the other two during daytime (between 3 and 5 times higher than the maximum emissions reported for the other cells). The emissions from these cells were not included in the comparison. Their exclusion does 

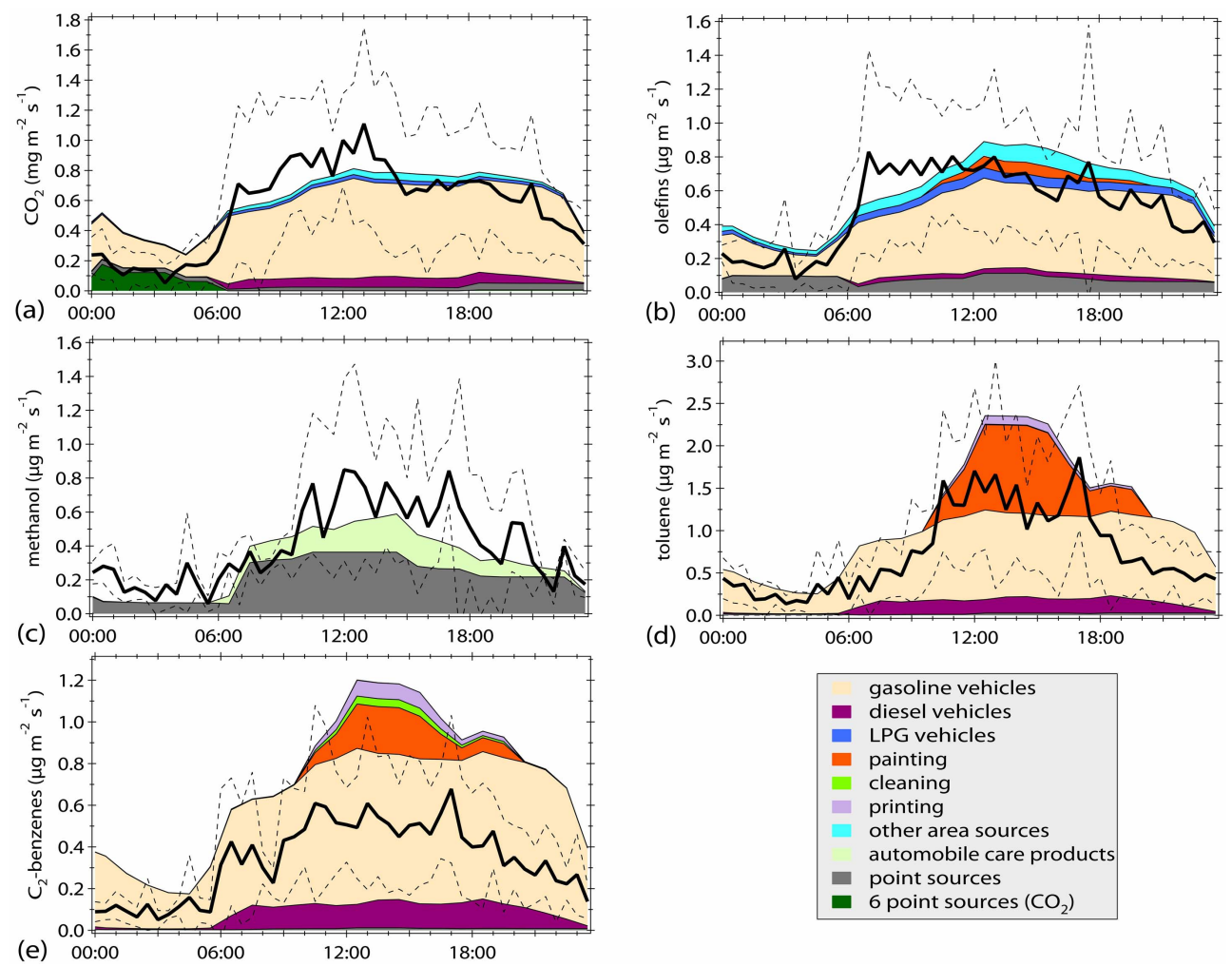

(d) $00: 00$

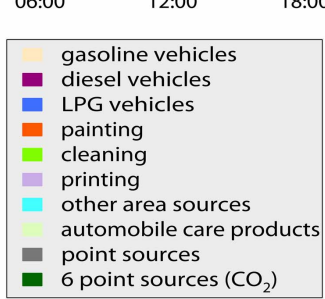

Fig. 9. Diurnal emission profiles distributed by source types for $\mathrm{CO}_{2}$ (a), olefins (b), methanol (c), toluene (d), and $\mathrm{C}_{2}$-benzenes (e). The emissions of $\mathrm{CO}_{2}$, olefins, toluene and $\mathrm{C}_{2}$-benzenes were extracted from the grid cells coinciding with the 6-h footprints obtained for different periods of the diurnal course, while the methanol emissions represent the 63 surrounding cells. The black lines correspond to the average fluxes measured during the entire field campaign, while the dashed lines indicate \pm 1 standard deviation of the measured fluxes.

not modify significantly the emission profiles since they are not included in all the evaluated footprints.

The emissions of olefinic VOCs in the inventory were weighted by their sensitivity response to the FOS listed in Table 2. For the other olefin species, we assumed null responses. Similarly, the $\mathrm{C}_{2}$-benzenes emissions correspond to the sum of ethylbenzene, benzaldehyde and the three xylene isomers.

Figure 8 shows the diurnal profiles of the measured fluxes along with the emission profiles obtained from the average footprint of the entire set of measured periods, the profile obtained from averaging the four 6-h footprints (diurnal footprint), and the 63 surrounding cells. In general, the best agreement between the measurements and the emissions inventory occurred with the diurnal footprint, except for methanol, as discussed later. In terms of species, $\mathrm{CO}_{2}$ and olefins show the best agreement between calculated emissions and measured fluxes. Figure 9 shows the diurnal emissions of $\mathrm{CO}_{2}$, olefins, toluene and $\mathrm{C}_{2}$-benzenes separated by major emission sources using the diurnal footprint. For methanol, emissions are referenced with respect to the 63 surrounding cells. For all species, according to the emissions inventory, with the exception of methanol, the mobile sources are the major contributors, with contributions of $87 \%$ for $\mathrm{CO}_{2}, 74 \%$ for olefins, $84 \%$ for $\mathrm{C}_{2}$-benzenes, and $72 \%$ for toluene on a daily averaged basis. Among the mobile sources, gasoline motor-vehicles are the principal contributors, as shown in Fig. 9. These contributions are consistent with the results found in the previous sections, with the exception of toluene, for which the traffic contribution was found to be lower. With regard to methanol, the emissions inventory indicated that methanol is emitted primarily from point sources and the use of auto-care products, with almost negligible evaporative contributions from adhesives, inks, pesticides and other domestic products. The emissions inventory does not report any vehicular contribution, contrary to results from other studies (Legreid et al., 2007) and our observed methanol correlations with $\mathrm{CO}_{2}$ flux and vehicular activity.

As mentioned before, the diurnal profiles of $\mathrm{CO}_{2}$ and olefin emissions from the emissions inventory follow closely the diurnal profiles of the measured fluxes. The emissions inventory agrees with the measured fluxes of $\mathrm{CO}_{2}$ and olefins to within $10 \%$ and $20 \%$, respectively. With the exception of the early morning period, the $\mathrm{CO}_{2}$ and olefin emissions were generally within the variability range of the measured fluxes. From midnight to 6 a.m., the emissions from the diurnal footprint and the 63 surrounding cells were larger than measured 
fluxes by factors of 2.3 and 1.7 for $\mathrm{CO}_{2}$ and olefins, respectively. This overestimation was due to 6 point sources with high emissions that were only included in the footprint during the stable nighttime period. Their contribution to the $\mathrm{CO}_{2}$ emissions is indicated in Fig. 9.

The human respiration is an additional $\mathrm{CO}_{2}$ source not accounted in the emissions inventory. Considering the local ambient conditions and average weight of a Mexican, we estimate that a person exhales $596 \mathrm{~g} \mathrm{CO}_{2}$ per day, which when multiplied by the population density showed that human respiration may account for $9 \%$ of the measured fluxes. During daytime, the human exhalation represents $6 \%$ of the $\mathrm{CO}_{2}$ emissions and this does not change the level of agreement between measured fluxes and estimated emissions, but at nighttime the human respiration could increase the over-prediction in the emissions inventory.

The species measured by PTR-MS and DEC show larger differences between measured fluxes and calculated emissions than for $\mathrm{CO}_{2}$ and olefins. On a daily basis, the emissions inventory overestimates the total $\mathrm{C}_{2}$-benzene flux by a factor of 2.1 for the average flux, and by 1.3 for the upper limit of the flux measurements. For toluene, the emissions inventory overestimates the average toluene flux by a factor of 1.6, but the emissions inventory is within the upper limit of the flux measurements throughout the diurnal period.

The estimated $\mathrm{C}_{2}$-benzenes emissions show a similar peak to the toluene emissions due to emissions from painting, cleaning and printing (see Fig. 9), but this was not apparent in the flux measurements. Between 9:30 a.m. and 8:30 p.m., when the emissions inventory reports these emissions, the $\mathrm{C}_{2}$-benzene emissions were 1.7 times higher than the upper limit of the fluxes defined by one standard deviation of the measurements. With these evaporative emissions removed from the inventory, the emissions inventory matches the upper limit of the fluxes during this period, with an average emission only $10 \%$ higher than the flux average. This observation suggests that mobile emissions are overestimated, since all evaporative emissions cannot be removed from the emissions inventory. In addition, for the rest of the day, when the inventory reports no evaporative emissions, the vehicular emissions are also overestimated. Nevertheless an overestimation in both, evaporative and mobile emissions cannot be ignored.

Considering that $27 \%$ of the toluene flux is due to mobile emissions during the resin application on the sidewalks near the tower and $45 \%$ during the rest of the day, as determined from the toluene to benzene flux ratio, it is clear that the toluene contribution from gasoline vehicles is overestimated in the emissions inventory. But it appears that the evaporative emissions are also overestimated. The toluene peak in the emissions inventory coincides with the observed peak in the flux measurements due to the resin application. However, if this resin had not been applied, the toluene overestimation in the emissions inventory would be even larger.
The emissions inventory shows a second peak in toluene and $\mathrm{C}_{2}$-benzenes emissions from 5:30 to 8:30 p.m. This evening peak corresponds to emissions from workshops, commerce and service establishments with a longer working schedule. However, the flux measurements of both species did not register this peak.

The similarity in the emissions profiles obtained for the 3 different footprints evaluated for $\mathrm{CO}_{2}$, olefins, toluene, and $\mathrm{C}_{2}$-benzenes indicates that the emissions of these species reported by the emissions inventory are homogeneously distributed within the analyzed district. However, the methanol emissions extracted from the average and diurnal footprints are always close to the lower limit of the flux measurements with a daily underestimation of $73 \%$. The emissions from the 63 surrounding cells include point sources whose emissions reduce the difference with the average flux measurements to $25 \%$ (see Fig. 8c). The origin of this underestimation appears to be the omission of methanol emissions from mobile sources or omission of point sources in the emissions inventory and less likely to the underestimation of evaporative emissions from households and lack of biomass burning emissions.

Overall, these results are consistent with the findings from the comparison between the 2003 flux measurements and the 2002 emissions inventory (Velasco et al., 2005a). For olefins, the estimated emissions were always within one standard deviation range of the measured fluxes, as well as for toluene. As in 2006, the 2002 emissions inventory overestimated the $\mathrm{C}_{2}$-benzenes emissions by a factor of 2 on a daily basis. For the location of the city in 2003, the emissions of toluene and $\mathrm{C}_{2}$-benzenes did not show the daytime peak from evaporative emissions. Methanol and $\mathrm{CO}_{2}$ were not specified in the 2002 emissions inventory; therefore a comparison was not possible.

Although these results do not address the full suite of VOC emissions, and together with the 2003 measurements, represent only two locations of the city, overall the findings suggest that the emissions inventory is relatively accurate for $\mathrm{CO}_{2}$ and olefins, but too high for $\mathrm{C}_{2}$-benzenes and toluene and too low for methanol. It seems that the emissions inventory predicts correctly the emissions from combustion sources, but overestimates the evaporative emissions from area sources, such as workshops, commerce and service establishments. These discrepancies can be expected for an urban area as diverse and as large as Mexico City, where the data to accurately determine the anthropogenic emissions is limited and comes from a multitude of sources.

Our results are consistent with those of Lei et al. (2007, 2008), who by indirect comparisons between modeled and observed ambient concentrations of VOCs from MCMA-2003 concluded that the emissions of olefins reported in the emissions inventory (for the years 2002 and 2004) are generally accurate, and the emissions of aromatics need to be adjusted by factors between 1 and 1.5 depending on the compound. These findings do not support the 
suggestion that $\mathrm{VOC}$ emissions are underestimated by factors ranging from 3 to 4 by West et al. (2004) and Arriaga-Colina et al. (2004).

\section{Conclusions}

The urban flux system deployed in Mexico City as part of the MILAGRO/MCMA-2006 field campaign showed agreement with the flux measurements collected during the MCMA2003 campaign from a different site within the city after accounting for differences in local traffic levels. The flux data collected in both studies indicate that the general constraints with the EC methods are satisfied and also that the measured fluxes are representative of emissions on the same scale as the resolution of typical urban emission inventories. Together, the data show that the emissions inventory is in reasonable agreement with measured olefin and $\mathrm{CO}_{2}$ fluxes, but $\mathrm{C}_{2}$-benzenes and toluene emissions from gasoline vehicles and evaporative sources are overestimated in the inventory. It appears that methanol emissions from mobile sources occur, but are not included in the emissions inventory. These conclusions are valid for the monitored sites, discrepancies with the emissions inventory might occur for other sectors of the city, in particular for industrial areas.

The flux measurements presented here demonstrated that the EC technique coupled with fast response sensors can be used to evaluate directly emission inventories in a way that is not possible with other indirect evaluation methods, making it a new and valuable tool for improving the air quality management process.

Acknowledgements. This study was supported by the National Science Foundation (ATM-0528227), Department of Energy (Award DE-FG02-05ER63980), the Comisión Ambiental Metropolitana of Mexico and the Molina Center for Strategic Studies in Energy and the Environment. The assistance and logistical support provided by the Atmospheric Monitoring System of the Federal District Government (SIMAT) was instrumental for the satisfactory development of this study. The authors acknowledge the constructive comments from the anonymous reviewer and the editor.

Edited by: S. Madronich

\section{References}

Amman, C., Brunner, A., Spirig, C., and Neftel, A.: Technical note: water vapour concentration and flux measurements with PTRMS, Atmos. Chem. Phys., 6, 4643-4651, 2006, http://www.atmos-chem-phys.net/6/4643/2006/.

Aubinet, M., Grelle, A., Ibrom, A., Rannik, Ü., Moncrieff, J., Foken, T., Kowalsky, A. S., Martin, P. H., Berbigier, P., Bernhofer, Ch., Clement, R., Elbers, J., Granier, A., Grünwald, T., Morgenstern, K., Pilegaard, K., Rebmann, C., Snijders, W., Valentini, R., and Vesela, T.: Estimates of the annual net carbon and water exchange of forests: the EUROFLUX methodology, Adv. Ecol. Res., 30, 113-175, 2000.
Auble, D. L., and Meyers, T. P.: An open path, fast response infrared absorption gas analyzer for $\mathrm{H}_{2} \mathrm{O}$ and $\mathrm{CO}_{2}$, Bound.-Layer Meteorol. 59, 243-256, 1992.

Arriaga-Colina, J. L.,West, J. J., Sosa, G., Escalona, S. S., Orduñez, R. M., and Cervantes, A. D. M.: Measurements of VOCs in Mexico City (1992-2001) and evaluation of VOCs and CO in the emissions inventory, Atmos. Environ., 38, 2523-2533, 2004.

Barletta, B., Meinardi, S., Rowland, F. S., Chan, C.-Y., Wang, X., Zou, S., Chan, L.-Y., and Blake, D. R.: Volatile organic compounds in 43 Chinese cities, Atmos. Environ. 39, 7706-7719, 2005.

de Gouw, J. and Warneke, C.: Measurements of volatile organic compounds in the Earth's atmosphere using proton-transferreaction mass spectrometry, Mass Spectrom. Rev., 26, 223-257, 2007.

Fast, J. D., de Foy, B., Acevedo Rosas, F., Caetano, E., Carmichael, G., Emmons, L., McKenna, D., Mena, M., Skamarock, W., Tie, X., Coulter, R. L., Barnard, J. C., Wiedinmyer, C., and Madronich, S.: A meteorological overview of the MILAGRO field campaigns, Atmos. Chem. Phys., 7, 2233-2257, 2007, http://www.atmos-chem-phys.net/7/2233/2007/.

Fortin, T. J., Howard, B. J., Parrish, D. D., Goldan, P. D., Kuster, W. C., Atlas, E. L., and Harley, R. A.: Temporal changes in U.S. benzene emissions inferred from atmospheric measurements, Environ. Sci. Technol., 39, 1403-1408, 2005.

Grimmond, C. S. B., King, T. S., Cropley, F. D., Nowak, D. J., and Souch, C.: Local-scale fluxes of carbon dioxide in urban environments: methodological challenges and results from Chicago, Environ. Pollut. 116, 243-254, 2002.

Grimmond, C. S. B. and Oke, T. R.: Aerodynamic properties of urban areas derived from analysis of surface form, J. App. Meteor., 38, 1262-1292, 1999.

Grivicke, R., Jimenez, J. L., Nemitz, E., Alexander, L., Velasco, E., Allwine, G., Pressley, S., Jobson, T., Molina, L. T., and Lamb, B.: Aerosol concentrations and fluxes in urban Mexico City during MILAGRO 2006, in preparation, 2009.

Guenther, A. B. and Hills, A.: Eddy covariance measurement of isoprene fluxes, J. Geophys. Res., 103, 13145-13152, 1998.

Holzinger, R., Williams, J., Salisbury, G., Klüpfel, T., de Reus, M., Traub, M., Crutzen, P. J., and Lelieveld, J.: Oxygenated compounds in aged biomass burning plumes over the Eastern Mediterranean: evidence for strong secondary production of methanol and acetone, Atmos. Chem. Phys., 5, 39-46, 2005, http://www.atmos-chem-phys.net/5/39/2005/.

Hsieh, C. I., Katul, G., and Chi, T.: An approximate analytical model for footprint estimation of scalar fluxes in thermally stratified atmospheric flows, Adv. Water Resour., 23, 765-772, 2000.

Jacob, D. J., Field, B. D., Li, Q., Blake, D. R., de Gouw, J., Warneke, C., Hansel, A., Wisthaler, A., Singh, H. B., and Guenther, A.: Global budget of methanol: constraints from atmospheric observations, J. Geophys. Res., 110, D08303, doi:10.1029/2004JD005172, 2005.

Karl, T., Apel, E., Hodzic, A., Riemer, D. D., Blake, D. R., and Wiedinmyer, C.: Emissions of volatile organic compounds inferred from airborne flux measurements over a megacity, Atmos. Chem. Phys., 9, 271-285, 2009, http://www.atmos-chem-phys.net/9/271/2009/.

Karl, T. G., Spirig, C., Rinne, J., Stroud, C., Prevost, P., Greenberg, J., Fall, R., and Guenther, A.: Virtual disjunct eddy covari- 
ance measurements of organic compound fluxes from a subalpine forest using proton transfer reaction mass spectrometry, Atmos. Chem. Phys., 2, 279-291, 2002, http://www.atmos-chem-phys.net/2/279/2002/.

Karl, T., Guenther, A., Lindinger, C., Jordan, A., Fall, R., and Lindinger, W.: Eddy covariance measurements of oxygenated volatile organic compound fluxes from crop harvesting using a redesigned proton-transfer-reaction mass spectrometer, J. Geophys. Res., 106, 24157-24167, 2001.

Legreid, G., Lööv, J. B., Staehelin, J., Hueglin, C., Hill, M., Buchmann, B., Prevot, A. S. H., and Reimann, S.: Oxygenated volatile organic compounds (OVOCs) at an urban background site in Zürich (Europe): seasonal variation and source allocation, Atmos. Environ., 41, 8409-8423, 2007.

Langford, B., Davison, B., Nemitz, E., and Hewitt, C. N.: Mixing ratios and eddy covariance flux measurements of volatile organic compounds from an urban canopy (Manchester, UK, Atmos. Chem. Phys., 9, 1971-1987, 2009,

http://www.atmos-chem-phys.net/9/1971/2009/.

Lei, W., Zavala, M., de Foy, B., Volkamer, R., Molina, M. J., and Molina, L. T.: Impact of primary formaldehyde on air pollution in the Mexico City Metropolitan Area, Atmos. Chem. Phys., 9, 2607-2618, 2009,

http://www.atmos-chem-phys.net/9/2607/2009/.

Lei, W., Zavala, M., de Foy, B., Volkamer, R., and Molina, L. T.: Characterizing ozone production and response under different meteorological conditions in Mexico City, Atmos. Chem. Phys., 8, 7571-7581, 2008, http://www.atmos-chem-phys.net/8/7571/2008/.

Lei, W., de Foy, B., Zavala, M., Volkamer, R., and Molina, L. T.: Characterizing ozone production in the Mexico City Metropolitan Area: a case study using a chemical transport model, Atmos. Chem. Phys., 7, 1347-1366, 2007,

http://www.atmos-chem-phys.net/7/1347/2007/.

Lindinger, W., Hansel, A., and Jordan, A.: On-line monitoring of volatile organic compounds at pptv levels by means of proton transfer-reaction mass spectroscopy (PTR-MS): medical applications, food control and environmental research, Int. J. Mass Spectrom. Ion Proc., 173, 191-241, 1998.

Massman, W. J. and Lee, X.: Eddy covariance flux corrections and uncertainties in long-term studies of carbon and energy exchanges, Agric. For. Meteor., 113, 121-144, 2002.

McMillen, R.: An eddy correlation technique with extended applicability to non-simple terrain, Bound.-Layer Meteorol., 43, 231245, 1988.

Molina, L. T., Madronich, S., Gaffney, J. S., and Singh, H. B.: Overview of MILAGRO/INTEX-B campaign, Newsletter of the International Atmospheric Chemistry Project, 38, 2-15, 2008.

Molina, L. T., Kolb, C. E., de Foy, B., Lamb, B. K., Brune, W. H., Jimenez, J. L., Ramos-Villegas, R., Sarmiento, J., ParamoFigueroa, V. H., Cardenas, B., Gutierrez-Avedoy, V., and Molina, M. J.: Air quality in North America's most populous city overview of the MCMA-2003 campaign, Atmos. Chem. Phys., 7, 2447-2473, 2007, http://www.atmos-chem-phys.net/7/2447/2007/.

Nemitz, E., Hargreaves, K. J., Mcdonald, A. G., Dorsey, J. R., Fowler, D.: Micrometeorological measurements of the urban heat budget and $\mathrm{CO}_{2}$ emissions on a city scale, Environ. Sci. Technol., 36, 3139-3146, 2002.
Pressley, S., Lamb, B., Westberg, H., Flaherty, J., Chen, J., and Vogel, C.: Long-term isoprene flux measurements above a northern hardwood forest, J. Geophys. Res, 110, D07301, doi:10.1029/2004JD005523, 2005.

Roth, M.: Review of atmospheric turbulence over cities, Q. J. Roy. Meteor. Soc., 126, 941-990, 2000.

Schmid, H. P., Grimmond, C. S. B., Cropley, F., Offerle, B., and $\mathrm{Su}, \mathrm{H}$. B.: Measurements of $\mathrm{CO}_{2}$ and energy fluxes over a mixed hardwood forest in the mid-western United States, Agric. For. Meteor., 103, 357-3774, 2000.

Schnitzhofer, R., Beauchamp, J., Dunkl, J., Wisthaler, A., Weber, A., and Hansel, A.: Long term measurements of $\mathrm{CO}, \mathrm{NO}, \mathrm{NO}_{2}$, benzene, toluene and $\mathrm{PM}_{10}$ at a motorway location in an Austrian valley, Atmos. Environ., 42, 1012-1024, 2008.

SMAGDF: Inventario de emisiones de contaminantes criterio de la Zona Metropolitana del Valle de México, Secretaría del Medio Ambiente del Gobierno del Distrito Federal, 2008.

Stephens, S., Madronich, S., Wu, F., Olson, J. B., Ramos, R., Retama, A., and Muñoz, R.: Weekly patterns of Mexico City's surface concentrations of $\mathrm{CO}, \mathrm{NO}_{\mathrm{x}}, \mathrm{PM}_{10}$ and $\mathrm{O}_{3}$ during 19862007, Atmos. Chem. Phys., 8, 5313-5325, 2008, http://www.atmos-chem-phys.net/8/5313/2008/.

Turnipseed, A. A., Pressley, S. N., Karl, T., Lamb, B., Nemitz, E., Allwine, E., Cooper, W. A., Shertz, S., and Guenther, A. B.: The use of disjunct eddy sampling methods for the determination of ecosystem level fluxes of trace gases, Atmos. Chem. Phys., 9, 981-994, 2009, http://www.atmos-chem-phys.net/9/981/2009/.

Velasco, E., Pressley, S., Grivicke, R., Allwine, E., Jobson, T., Westberg, H., Molina, L. T., and Lamb, B.: VOC flux measurements by disjunct eddy accumulation from an urban footprint, in preparation, 2009a.

Velasco, E., Pressley, S., Grivicke, R., Allwine, E., Molina, L. T., and Lamb, B.: Energy balance in urban Mexico City: observations and parameterization during the MILAGRO-2006 field campaign, in preparation, 2009b.

Velasco, E., Lamb, B., Westeberg, H., Allwine, E., Sosa, G., Arriaga-Colina, J. L., Jonson, B. T., Alexander, M. L., Prazeller, P., Knighton, W. B., Rogers, T. M., Grutter, M., Herndon, S. C., Kolb, C. E., Zavala, M., de Foy, B., Volkamer, R., Molina, L. T., and Molina, M. J.: Distribution, magnitudes, reactivities, ratios and diurnal patterns of volatile organic compounds in the Valley of Mexico during the MCMA 2002 \& 2003 field campaigns, Atmos. Chem. Phys., 7, 329-353, 2007, http://www.atmos-chem-phys.net/7/329/2007/.

Velasco, E., Lamb, B., Pressley, S., Allwine, E., Westberg, H., Jobson, B. T., Alexander, M., Prazeller, P., Molina, L., and Molina, M.: Flux measurements of volatile organic compounds from an urban landscape, Geophys. Res. Lett., 32, L20802, doi:10.1029/2005GL023356, 2005a.

Velasco, E., Pressley, S., Allwine, E., Westberg, H., and Lamb, B.: Measurements of $\mathrm{CO}_{2}$ fluxes from the Mexico City urban landscape. Atmos. Environ. 39, 7433-7446, 2005b.

Vesala, T., Kljun, N., Rannik, Ü., Rinne, J., Sogachev, A., Markkanen, T., Sabelfeld, K., Foken, Th., and Leclerc, M. Y.: Flux and concentration footprint modeling: state of the art, Environ. Pollut., 152, 653-666, 2008.

West, J., Zavala, M. A., Molina, L. T., Molina, M. J., San Martini, F., McRae, J., Sosa, G., and Arriaga-Colina, J. L.: Model- 
ing ozone photochemistry and evaluation of hydrocarbon emissions in the Mexico City metropolitan area, J. Geophys. Res., 109, 19312-19327, 2004.

Westberg, H., Lamb, B., Hafer, R., Hills, A., Shepson, P., and Vogel, C.: Measurement of isoprene fluxes at the PROPHET site, J. Geophys. Res., 106, 24347-24358, 2001.

Zavala, M., Herndon, S. C., Wood, E. C., Onasch, T. B., Knighton, W. B., Kolb, C. E., and Molina, L. T.: Evaluation of mobile emissions contributions to Mexico City's emissions inventory using on-road and cross-road emission measurements and ambient data, Atmos. Chem. Phys., 9, 6305-6317, 2009,

http://www.atmos-chem-phys.net/9/6305/2009/.
Zavala, M., Herndon, S. C., Slott, R. S., Dunlea, E. J., Marr, L. C., Shorter, J. H., Zahniser, M., Knighton, W. B., Rogers, T. M., Kolb, C. E., Molina, L. T., and Molina, M. J.: Characterization of on-road vehicle emissions in the Mexico City Metropolitan Area using a mobile laboratory in chase and fleet average measurement modes during the MCMA-2003 field campaign, Atmos. Chem. Phys., 6, 5129-5142, 2006,

http://www.atmos-chem-phys.net/6/5129/2006/. 